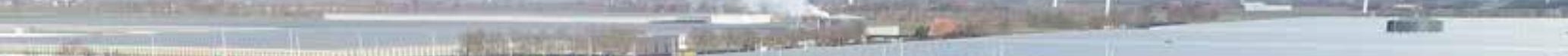



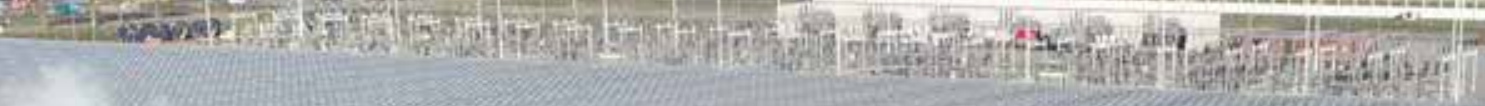

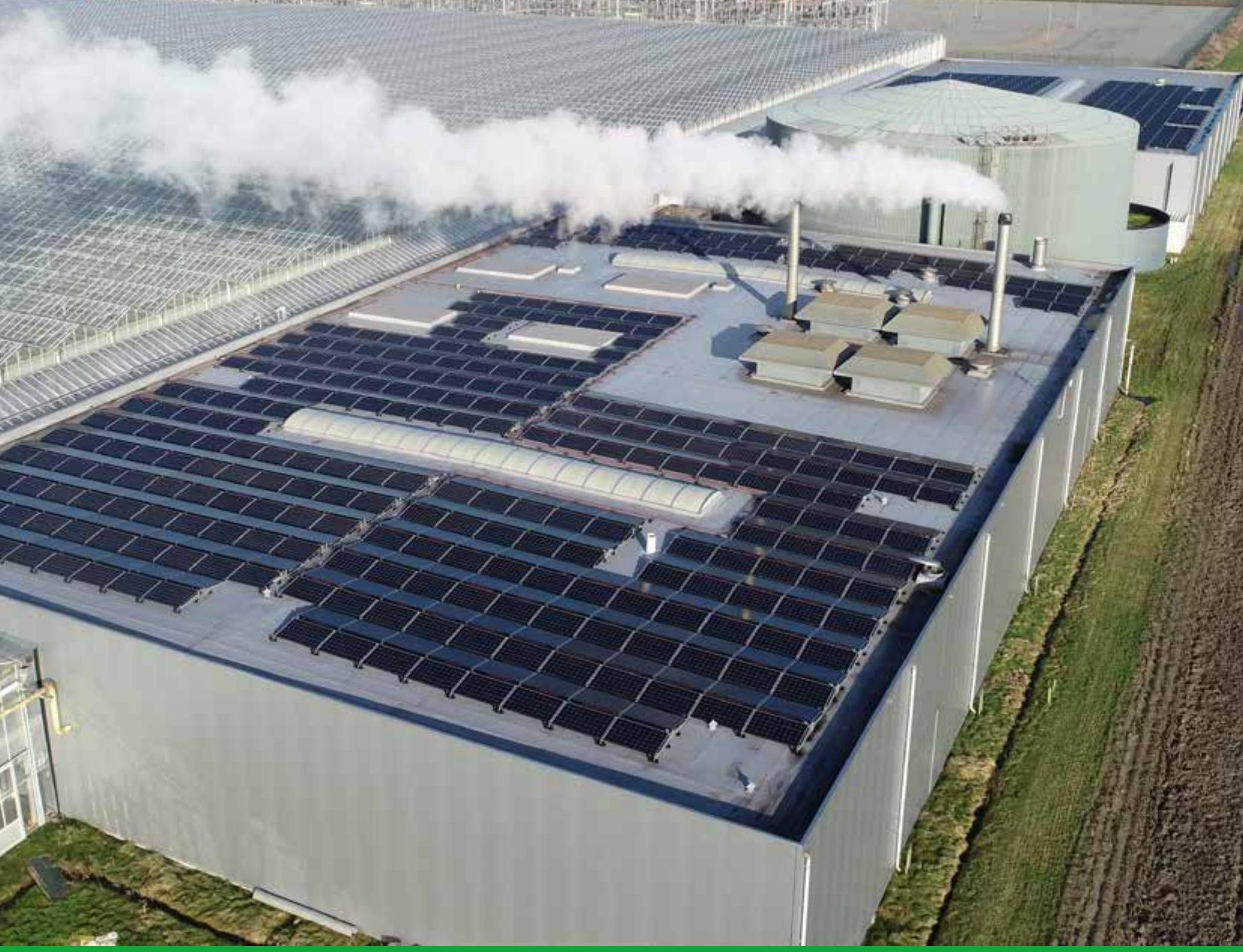

\title{
AgTech Ecosystem Kentucky: Inception study
}





\section{AgTech Ecosystem Kentucky: Inception study}

M. Ruijs, W. Hennen, P. Ravensbergen

This study has been executed by Wageningen Economic Research, part of Stichting Wageningen Research, commissioned by NL Works / Netherlands Enterprise Agency (RVO).

Wageningen Economic Research

Wageningen, July 2021

REPORT

2021-090

ISBN 978-94-6395-881-3 
M. Ruijs, W. Hennen, P. Ravensbergen, 2021. AgTech Ecosystem Kentucky: Inception study. Wageningen, Wageningen Economic Research, Report 2021-090. 50 pp.; 14 fig.; 0 tab.; 17 ref. This Inception study is commissioned by NL Works / Netherlands Enterprise Agency (RVO).

Een inceptie studie is uitgevoerd van een voorgenomen haalbaarheidsstudie naar de kansen van AgTech ecosysteem ontwikkeling, in het bijzonder de glastuinbouw, in Kentucky. De huidige situatie en mogelijke vervolgstappen zijn in kaart gebracht door een ruimtelijke analyse van productielocaties voor de glastuinbouw, een markt en ketenanalyse, technische analyse van verduurzaming van de productie en het governance aspect. Tevens zijn obstakels en kansen voor het Nederlands en Kentucky (tuinbouw)bedrijfsleven beschreven. De studie levert op genoemde aspecten aanbevelingen op voor vervolg activiteiten om de AgTech ecosysteem ontwikkeling mogelijk te maken.

An inception study has been conducted of an intended feasibility study into the opportunities of AgTech ecosystem development, in particular greenhouse horticulture, in Kentucky. The current situation and possible follow-up steps have been mapped out by means of a spatial analysis of production locations for greenhouse horticulture, a market and value chain analysis, technical analysis of making production more sustainable and the governance aspect. Obstacles and opportunities for the Dutch and Kentucky (horticultural) industry are also described. The study provides recommendations on these aspects for follow-up activities to enable AgTech ecosystem development.

Key words: AgTech Ecosystem development, spatial, market and value chain and technical analysis, governance aspects and business opportunities for Dutch and Kentucky companies

This report can be downloaded for free at https://doi.org/10.18174/549613 or at www.wur.eu/economic-research (under Wageningen Economic Research publications).

(C) 2021 Wageningen Economic Research

P.O. Box 29703, 2502 LS The Hague, The Netherlands, T +31 (0)70 3358330 ,

E communications.ssg@wur.nl, http://www.wur.eu/economic-research. Wageningen Economic Research is part of Wageningen University \& Research.

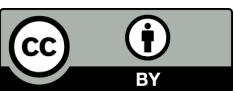

(C) 2021 by Wageningen Economic Research, licensed under CC BY 4.0, attribution not necessary. To view a copy of this license, visit http://creativecommons.org/licenses/by/4.0/.

Wageningen Economic Research accepts no liability for any damage resulting from the use of the results of this study or the application of the advice contained in it.

Wageningen Economic Research is ISO 9001:2015 certified.

Wageningen Economic Research Report 2021-090 | Project code 2282200659

Cover photo: (C) Agriport A7 BV 


\section{Contents}

$\begin{array}{ll}\text { Preface } & 5\end{array}$

$\begin{array}{ll}\text { Summary } & 6\end{array}$

S.1 Primary outcomes $\quad 6$

$\begin{array}{lll}\text { S.2 Other outcomes } & 6\end{array}$

$\begin{array}{ll}\text { S.3 Method } & 7\end{array}$

1

$\begin{array}{ll}\text { Introduction } & \mathbf{8}\end{array}$

1.1 Background $\quad 8$

$\begin{array}{lll}1.2 & \text { Objective } & 9\end{array}$

$\begin{array}{lll}1.3 & \text { Reading guide } & 9\end{array}$

2

$\begin{array}{ll}\text { Approach } & 10\end{array}$

2.1 Spatial analysis $\quad 10$

2.2 Definition phase 10

3

$\begin{array}{ll}\text { Results Spatial Analysis } & 12\end{array}$

3.1 Current situation $\quad 12$

3.2 High potential areas $\quad 15$

$\begin{array}{lll}3.3 & \text { Project-based location } & 16\end{array}$

$\begin{array}{lll}3.4 & \text { Next steps } & 16\end{array}$

$\begin{array}{llr}4 & \text { Results definition phase } & 18\end{array}$

$\begin{array}{lll}4.1 & \text { Market and value chain } & 18\end{array}$

4.1.1 Current situation 18

4.1.2 Next steps 19

$\begin{array}{lll}4.1 .3 \text { Remarks } & 20\end{array}$

4.2 Technical aspects of greenhouse production 20

4.2.1 Current situation $\quad 20$

$\begin{array}{ll}4.2 .2 \text { Next steps } & 22\end{array}$

$\begin{array}{lll}4.3 & \text { Governance \& design ecosystem } & 27\end{array}$

4.3.1 Current situation $\quad 27$

$\begin{array}{ll}\text { 4.3.2 Next steps } & 28\end{array}$

4.4 Potential barriers and opportunities for Dutch and Kentucky businesses 31

4.4.1 Potential barriers $\quad 32$

4.4.2 Potential opportunities $\quad 32$

$\begin{array}{lll}5.1 & \text { Conclusions } & 34\end{array}$

5.1.1 Spatial analysis 34

5.1.2 Market and chain analysis $\quad 34$

$\begin{array}{ll}5.1 .3 \text { Technical analysis } & 34\end{array}$

$\begin{array}{ll}5.1 .4 \text { Governance } & 35\end{array}$

5.1.5 Potential opportunities and barriers for Dutch and Kentucky/US $\begin{array}{ll}\text { companies for doing business } & 35\end{array}$

5.2 Recommendation for follow-up research $\quad 35$

$\begin{array}{ll}\text { References and websites } & 38\end{array}$ 
Appendix 1 Kentucky AgTech Ecosystem Consortium Collaboration Agreement (signed by 17 parties)

Appendix 2 Suitable greenhouse investments in Kentucky (Hennen en Ruijs, 2021) 


\section{Preface}

This study describes the inception phase of an intended feasibility study with regard to the opportunities for an AgTech Ecosystem development, in particular greenhouse horticulture, in Kentucky. It also indicates the opportunities and barriers for Dutch and Kentucky businesses to expand their activities.

The assignment has been commissioned by NLWorks. Wageningen Economic Research was contracted to conduct this inception study.

The study describes the outcomes of the inception phase and includes a market-, governance-, technical- and spatial analysis and provides recommendations for follow-up activities. The outcomes are based on existing literature, analysis and a consultation of stakeholders. The report includes a PowerPoint document with a spatial analysis of the suitability of greenhouse horticultural production.

We hope that the deliverables of this inception study will help the Kentucky private and public sector in collaboration with the Dutch private and public sector to achieve their goals in a follow-up project of the feasibility study.

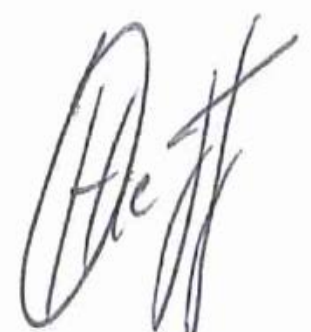

Ir. O. (Olaf) Hietbrink

Business Unit Manager Wageningen Economic Research

Wageningen University \& Research 


\section{Summary}

\section{S.1 Primary outcomes}

To achieve an AgTech Ecosystem development in Kentucky education and training at all levels should have the highest priority. In the short term, basic education and practical training is needed for greenhouse employees to increase their knowledge and skills. In the mid and long term, education on all levels from vocational to academic degree programs is needed, covering different subjects in production and the horticultural value chain, such as crop management, climate control, waste management and logistics. In this perspective the assessment of a Kentucky HortiCenter is an important follow-up study. Also the Dutch Triple Helix model and the Agricultural Knowledge and Innovation System (AKIS) can be used to determine which education programs and research activities can be developed.

With regard to governance, attention should be paid to new parties which can add value and/or broaden the activities of the current consortium regarding the AgTech Ecosystem development. These new actors are very likely to increase economic significance and sustainability. This can be parties inside the horticultural value chain, such as producers, logistic and packaging, or outside the horticultural value chain, such as providers of renewable energy, waste valuation and the food industry. Some parties are already interested. Broadening the current consortium will certainly strengthen the AgTech Ecosystem development.

The Kentucky government can play a greater role in supporting the establishment of greenhouses and providing horticultural (related) education. This refers to spatial, legal and financial instruments. Further studies should reveal exactly what this means in practice. In this perspective the experiences and insights of new horticultural areas in the Netherlands could be useful for developing the AgTech Ecosystem in Kentucky.

Based on the spatial analysis, Central Kentucky appears to be the most suitable area for AgTech Ecosystem development and in particular for a project-based location of greenhouses and other related activities within and outside the value chain. Most relevant factor is the favorable location in relation to other parties within and outside the supply chain. Colocation with parties such as energy providers can further improve the sustainability. Nevertheless, a more detailed study is needed to identify specific areas for project-based locations with colocation of greenhouses and other supporting sectors.

\section{S.2 Other outcomes}

The development of an AgTech Ecosystem aims at creating new economic development and a sustainable $\&$ healthy food production system that can provide sustainable jobs and create locally grown, healthier food at affordable prices for consumers in the US, while reducing the use of land, water, and fossil fuels.

Additional technical analyses are needed to further investigate the sustainability and viability of greenhouse production in Kentucky. Special attention should be paid to renewable energy sources and delivery of $\mathrm{CO}_{2}$. Integrated pest management, nutrient management, water management, waste management and waste evaluation must also be given attention.

Opportunities for Dutch and US private companies are unlimited. Dutch greenhouse input and service suppliers can benefit from the AgTech Ecosystem development by providing products and services. On the US side, companies in and outside the horticultural value chain may benefit when they support or strengthen the ecosystem development. This refers to companies in the field of logistics, packaging, energy supply, waste management, robotics and food processing. 


\section{S.3 Method}

The study is commissioned by NLWorks. The inception study was conducted by Wageningen Economic Research in 2021 and is based on existing literature, consultation with Kentucky and Dutch stakeholders and a spatial analysis with the Wageningen Economic Research tool Global Detector. Global Detector is a knowledge-based geographical information system. Additional regional information and data, in particularly on energy sources, has been provided by the Commonwealth of Kentucky, Cabinet for Economic Development, the University of Pikeville, and University of Kentucky. 


\section{Introduction}

\section{$1.1 \quad$ Background}

The US and Dutch public and private partners have initiated a multiannual public-private collaboration program focused on transforming the Bluegrass State Kentucky into a Controlled Environmental Agriculture State. A collaboration agreement between the (17) partners (see Appendix 1) was signed in June 2020 and includes a shared ambition in establishing a growth model towards an AgTech Ecosystem in Kentucky. This collaboration aims at creating a sustainable \& healthy food production system that can provide sustainable jobs and create locally grown, healthier food at affordable prices for consumers in the US, while reducing the use of land, water, and fossil fuels. A leading party in this collaboration is the Kentucky company AppHarvest. AppHarvest has launched its first high-tech greenhouse in Morehead, Kentucky, and has a mission to feed the future from the heart of Appalachia. ${ }^{1}$ Currently AppHarvest produces tomatoes and will soon expand to fruits and leafy greens.

An AgTech Ecosystem is a controlled environment agriculture network, which includes an 'ecosystem' of production, supplying industry, logistics, trade, and retail, facilitated by education, Research \& Development, government support, finance infrastructure, and other services (Kuhlman and Arnold, 2001, Hekkert et al., 2007, Smeets et al., 2015). The whole of activities and services determines the strength of the cluster or ecosystem (see box Five principles).

\section{Box: Five important principles to achieve an AgTech ecosystem}

1. Resource use efficiency The key is an integrated approach for the highest possible yield in a specific setting with the least possible use of energy, water, nutrients, other production factors and space.

2. Vertical integration

The aim is to integrate the different steps in a specific production chain from primary production to retail, in order to improve co-operation between the activities and also to be able to capture a larger part of the added value that is produced in the chain as a whole.

3. Horizontal integration

The aim is to optimize waste management, by a skillful combination of agricultural production chains with itself and other chains, in which the waste stream from one element function as resource for other elements as much as possible.

4. Agrologistics

The aim is to keep the products as fresh as possible from harvest to the final customer. This requires good infrastructure, transportation means, locations/hubs for consolidation, access to import/export locations, T\&T, packaging and quality control systems.

5. Integral design of hardware, orgware and software

Successful innovation systems are based on the integrated approach of technology (the 'hardware'), the business design and governance ('orgware') and knowledge and exchange of knowledge ('software').

1 www.appharvest.com 
To judge the opportunities of an AgTech Ecosystem, a feasibility design study is desired. This will deliver insights into the technical, economic, sustainability, and societal feasibilities and help determine the optimal design for the AgTech ecosystem. This will help the US and Dutch public and private partners in achieving shared goals. In the proposed feasibility study, the following topics will be reviewed, based on previous studies (as mentioned above the box):

1. Spatial analysis: what are suitable areas (including expanding possibilities) for greenhouse production taking into account biophysical conditions, such as climate, infrastructure, and land characteristics;

2. Market analysis: type of value chain (value chain is related to the supply chain and includes input suppliers, production, packaging and logistics), key market drivers in the value chain;

3. Technology analysis: short-/mid-term opportunities for technology adoption and long-term challenges; and

4. Governance analysis: required actors, ways of public-private interactions and organizational steering structures, and public (government and educational) interests in sustainable food production.

The feasibility study starts with an inception study, being this study, which is intended as an input for the design of this feasibility study.

To speed up this initiative, NLWorks, as a neutral party, is designated to coordinate.

\subsection{Objective}

The overall objective is to develop a coherent vision of an AgTech ecosystem and the steps needed to achieve this ecosystem. The objective of this inception study is to assess what next steps are needed in terms of follow up research to develop an AgTech ecosystem and to determine what potential barriers and opportunities exist for the Dutch businesses in the efforts to expand their market entrance and to scale up their activities in Kentucky. This study will also inform the Kentucky State Government and partners with the next steps, research questions and which approach to follow.

\subsection{Reading guide}

Chapter 2 describes the approach of this study. In Chapter 3 the results will be discussed with respect to the spatial analysis and in Chapter 4 the results, concerning the market analysis, governance and technology analysis, and the barriers and opportunities for Dutch and Kentucky businesses. The conclusions and recommendations follow in Chapter 5. 


\section{Approach}

The inception study is divided into two parts: 1 . Spatial analysis and 2. Definition phase. The definition phase covers the entire ecosystem including private and public parties around the value chain, while the spatial analysis focuses on suitable areas for sustainable greenhouse production.

\section{$2.1 \quad$ Spatial analysis}

In the inception study specific attention is paid to the biophysical conditions for greenhouse development in Kentucky. The spatial analysis indicates the potential for greenhouse production in Kentucky. This is conducted with the Global-Detector ${ }^{\odot}$ tool developed by Wageningen Economic Research. Five Advisory Board members from different stakeholder groups were consulted (see consulted persons in Reference list), who shared their opinions and expertise on the outcome of the Global-Detector maps.

Global-Detector is a knowledge-based Geographic Information System for spatial analysis that aims to detect the potential for production, demand and market strategies. This tool is developed by Wageningen Economic Research (Hennen et al., 2017), a research initiative of Wageningen University and Research. The tool can, in a grid-level of $10 \times 10 \mathrm{~km}$, show the values from a large number of indicators and combine a selection of indicators to yield a potential map. For this Kentucky study, all data are converted to $2.5 \times 2.5 \mathrm{~km}^{2}$ [USA Contiguous Albers equal area projection]. Global-Detector contains indicators for climate (e.g. monthly temperature, solar irradiation, precipitation), infrastructure (e.g. distance to markets), land characteristics (e.g. slope), land utilization (e.g. \% cropland, protected areas), population density and number of people in radius (e.g. 20 or $250 \mathrm{~km}$ ), possibilities for production near cities, and miscellaneous indicators (e.g. nightlight). Knowledge from (local) experts and relevant indicators per aspect (e.g. climate) are combined to yield the potential map. For the potential of greenhouse production, additional detailed information from the region has been used to improve the assessment of the potential, e.g. availability of energy, water resources (e.g. aquifers), locations of logistic centers.

Additional regional information and data, in particular on energy sources, has been provided by the Commonwealth of Kentucky, Cabinet for Economic Development, the University of Pikeville, and the University of Kentucky.

The spatial analysis has delivered a map indicating the potential for greenhouse production in Kentucky (see Appendix 2: a PPT as separate document to this report; Hennen and Ruijs, 2021). It gives a first insight into the biophysical conditions in Kentucky for greenhouse development in the transition towards an AgTech Ecosystem. The results are described in Chapter 3.

\subsection{Definition phase}

In the definition phase, the objective is to describe the next steps in achieving an AgTech Ecosystem and what follow up research it will require. Also, the potential barriers and opportunities for Dutch and Kentucky businesses will be indicated.

An ecosystem includes the integration of 'hardware, software and orgware'.

- 'Hardware'. the physical and technical aspects of greenhouse production, such as greenhouse structure, production techniques, energy and water supply, integrated pest management, etc., and other links 
in the supply chain, such as cold storage facilities, availability of sufficient transportation packaging material and IT systems;

- 'Software'

the skills and knowledge of the main actors in the chain. Skills and knowledge can be in the technical field (good agricultural practices, post-harvest handling and value addition, sorting/grading/cleaning activities), but also the field of organization and collective action (cooperative, collection centers, service center, collective action). One very important aspect is how to improve skills throughout the chain, including skills in production, collective action, marketing, and entrepreneurship. Other topics include integration and connection of education and research institutes with the private sector, co-creation of tailor-made training modules and training and capacity building roles and responsibilities throughout the chain;

- 'Orgware' the structure and organization of the value chain, such as quality standards, food safety, phytosanitary controls, agri-business clusters, and networks and business models.

For a successful realization of the AgTech Ecosystem it is very important to integrate all 3 aspects: hardware, software, and orgware. If only one or two aspects are addressed, there is a risk that it will not be a success. In a feasibility study, it is important to analyze whether these aspects are considered and how they are integrated.

The hardware, software and orgware approach is concretized in the analysis of:

1. market and value chain

2. technical aspects of greenhouse production

3. governance aspects \& design of ecosystem

4. potential barriers and opportunities for Dutch and Kentucky businesses.

Information is gathered through literature review and consultation of involved parties in the consortium (see Appendix 1). Feedback on the preliminary results is provided by the Advisory Board, which is composed of representatives of the consortium. A questionnaire was used to collect views, opinions, thoughts and suggestions regarding the development of an AgTech Ecosystem in Kentucky. The same five stakeholders from the Advisory Board were consulted as in the Spatial Analysis phase. They shared their opinions and expertise on the different topics of market and chain, technical aspects, governance aspects, and potential barriers and opportunities for Dutch and Kentucky businesses.

Described in Chapter 4, the definition phase will deliver a description of the current situation and an overview of the next (or needed) steps and activities per theme for a follow-up feasibility study. 


\section{Results Spatial Analysis}

\section{$3.1 \quad$ Current situation}

Besides developments at farm/business levels, area features will determine the possibilities and opportunities for AgTech ecosystem development. This includes the availability of land for establishing greenhouses, the climate, infrastructure, resources and consumer markets. In more detail, the potential for greenhouse production has been analyzed with help of the Global-Detector tool. For more information see Appendix 2 'Suitable greenhouse investments in Kentucky' (Hennen and Ruijs, 2021). The focus is on the suitability of glass greenhouses where the climate can be controlled almost completely, as applied in the Netherlands, and which can be defined as high-tech greenhouses. This compares to mid-tech (mostly greenhouses of hard plastic plates with limited climate control possibilities) and low-tech greenhouses (simple soft plastic tunnels with very limited climate control possibilities).

With respect to the aspect 'climate and water availability', the following indicators were taken into account: temperature, solar radiation, humidity, risk of snow cover, and water availability (precipitation and rivers \& lakes). The results pointed out that climate and water availability has limited distinction in Kentucky. Climate is fairly even and favorable for greenhouse development (see Figure 3.1). Extremes in climate are rare and there is low variation in solar radiation and humidity. Water availability appears to be fairly sufficient based on average figures. At local levels there will be some climate differences. Within the USA, differences range from 0 to 1 .



Figure 3.1 Suitable area for greenhouse production in Kentucky based on aspect Climate and water availability (scale: $0-1$, where 1 is most suitable; green areas have the highest potential)

The 'Infrastructure' aspect includes the indicators of road density and quality, availability of railroads, the proximity of airports, travel time to cities (including labor) and population size. Results are shown in Figure 3.2. 


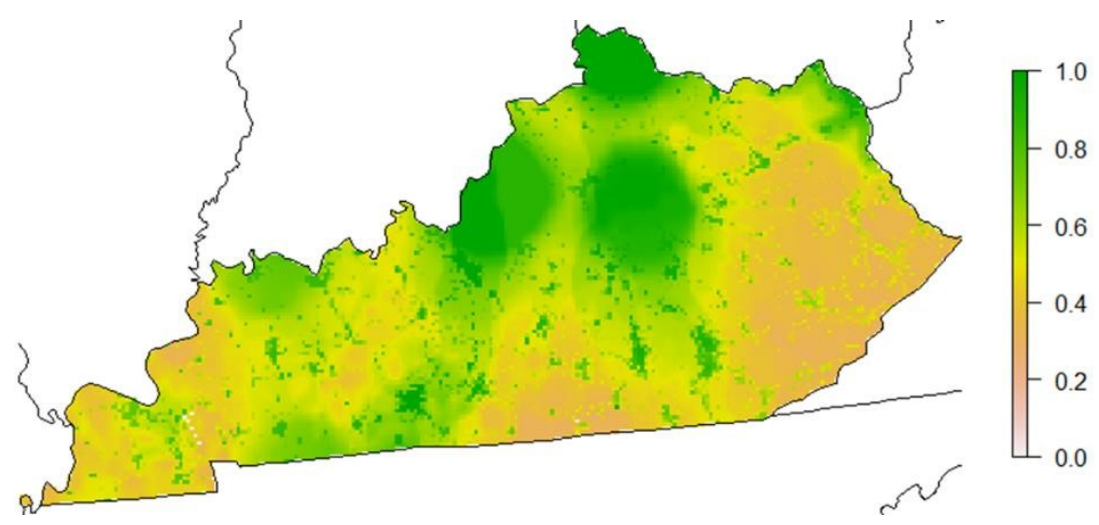

Figure 3.2 Suitable area for greenhouse production in Kentucky based on Infrastructure aspect (scale: $0-1$, where 1 is most suitable; green areas have the highest potential)

Figure 3.2 points out that suitable areas for greenhouse production are located around cities and (rail)roads. The state of Kentucky is located strategically with the presence of various logistics hubs. Three major shipping hubs (UPS, DHL and Amazon) are located at Kentucky's two area international airports (Louisville and Cincinnati). Infrastructure is scored fair to good based on the number of (rail)roads, (navigable) waterways and commercial airports (Info Team Kentucky, Cabinet for Economic Development; Just the Facts: Logistics and Distribution). About two-thirds of the US population and market is within a day's drive of Kentucky.

The availability of land for greenhouse production depends to a large extent on the land characteristics. Availability of land is more favorable when it is not too covered with forests and grassland, does not have high altitude, has no high slope, and population density is not too high. Protected areas are excluded as a suitable area for greenhouse production. The cost or availability of land for development were not taken into account. The results are illustrated in Figure 3.3, protected areas are purple.

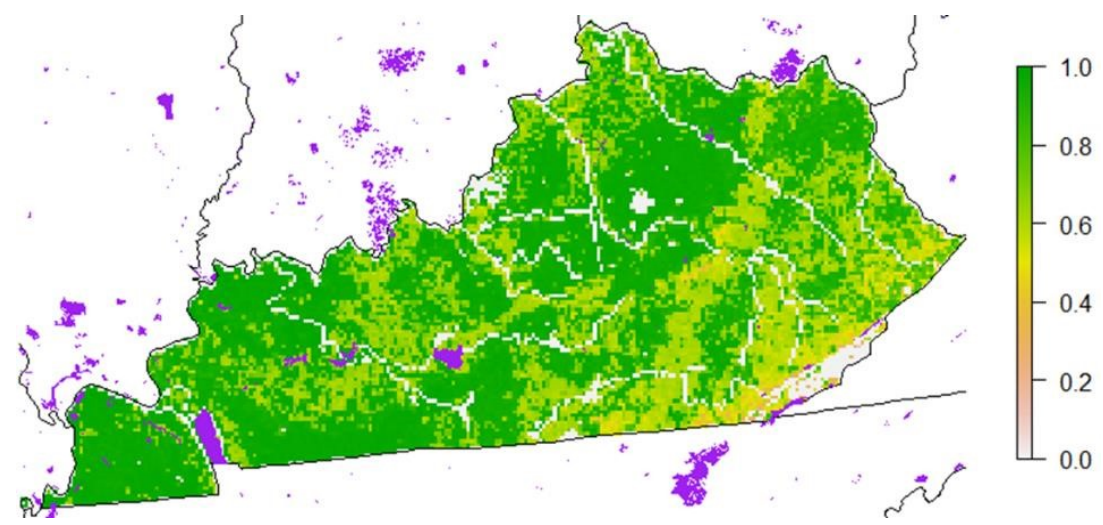

Figure 3.3 Suitable area for greenhouse production in Kentucky based on aspect Land characteristics (green areas have the highest potential). Purple colored areas are protected areas. (scale: $0-1$, where 1 is most suitable; green areas have highest potential)

Figure 3.3. shows that much of Kentucky is suitable for greenhouse production. There is plenty of farmland, but in Eastern Kentucky contiguous areas greater than 50 acres that are suitable for greenhouses are limited.

An important factor in the search for suitable area for high-tech greenhouses is the availability of energy (resources). In this regard, the energy aspect includes power plants, small hydro-electric, biomass, geothermal resources, solar photovoltaic and gas pipelines. Additional energy data was provided by the Kentucky state government. The results are shown in Figure 3.4. 




Figure 3.4 Suitable area for greenhouse production in Kentucky based on Energy aspect (scale: $0-1$, where 1 is most suitable; green areas have highest potential).

$\triangle$ power plant, small hydro

The availability of energy for greenhouse production depends on a large extent on the regional available energy resources.

Although coal in 2019 is Kentucky's primary energy source, the state also produces oil and natural gas. Kentucky is the fifth-largest coal producing state in the United States, producing the coal needed to fuel 59 power plants in 13 states. Coal accounts for 75\% of Kentucky's electricity portfolio and 39\% of its total energy consumption. Kentucky also has growing renewable energy resources and opportunities (Bone, 2020).

The main renewable energy sources in Kentucky are currently hydro and biomass, along with solar (Info: Kentucky state government). Hydro, biomass and solar are readily accessible renewable energy options. Biomass (biopower potential estimate based on available residue data) is more present in the western part of Kentucky.

Geothermal energy seems less favorable as renewable energy source in Kentucky because it has the lowest class indication. The 'Geothermal (EGS)' map $^{2}$ has 5 categories for the US with values ranging 'Class 1 ' to 'Class 5'. Classes express approximate favorability for geothermal resource, with a lower number indicating the possibility of a higher potential value. The state of Kentucky has 2 of these classes: 'Class 4 ' and 'Class 5', so this indicates low potential value of geothermal energy.

A point of attention is the availability of $\mathrm{CO}_{2}$ for plant production (not included in the results) when (more) renewable energy will be used. Renewable energy does not always generate $\mathrm{CO}_{2}$ in addition to heat and electricity, which is an important production factor. Are there alternatives in Kentucky concerning the availability of pure $\mathrm{CO}_{2}$ or $\mathrm{CO}_{2}$ from (heavy) industry? In the latter case, $\mathrm{CO}_{2} \mathrm{Could}_{\text {be }}$ captured and supplied to greenhouse horticulture not too far from this industry.

2 https://maps.nrel.gov/re-atlas/ 


\subsection{High potential areas}

When all four aspects (climate and water availability, infrastructure, land characteristics, and energy) are considered together, the following map displays suitable areas for high-tech greenhouse production (see Figure 3.5).

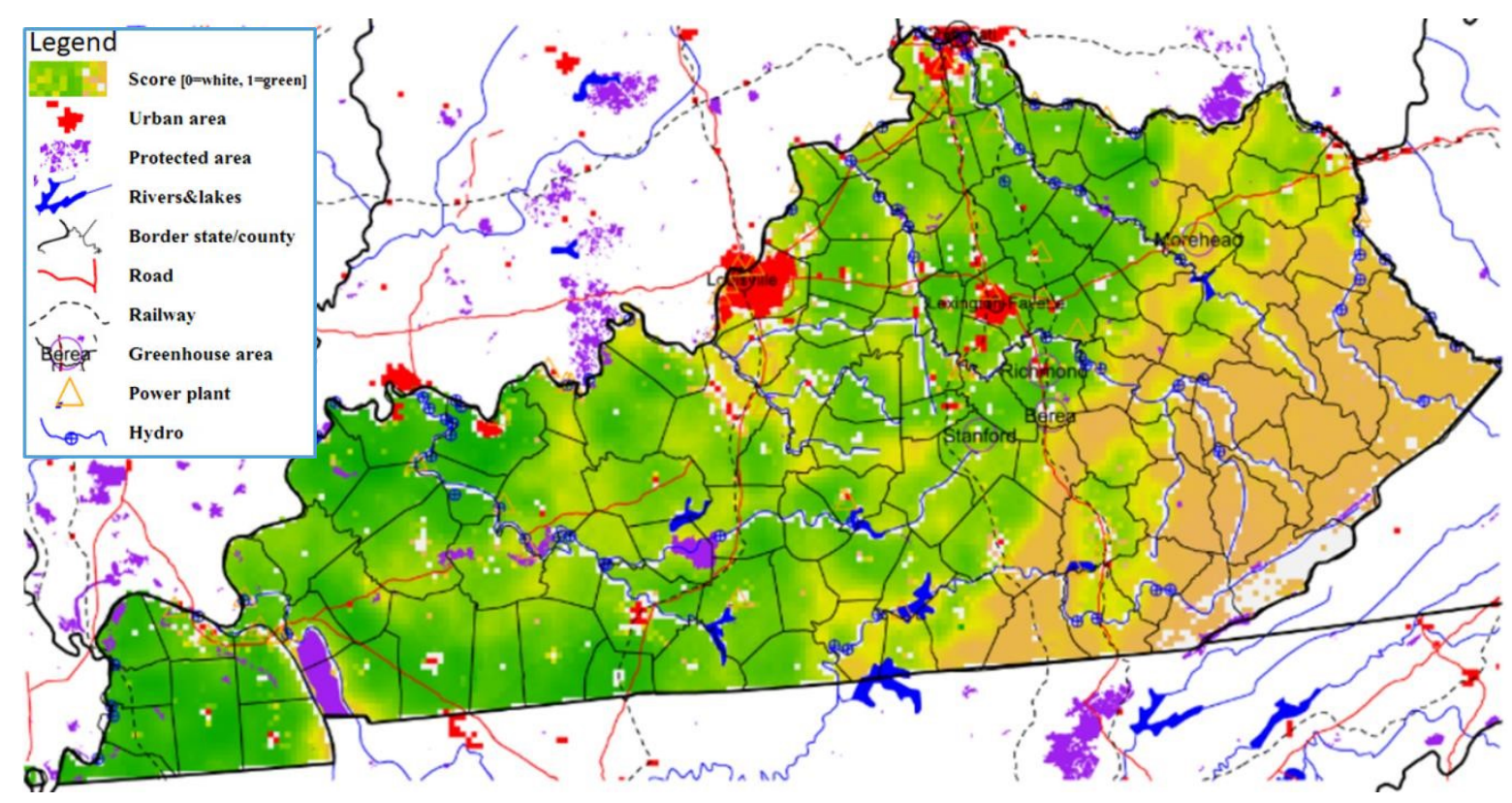

Figure 3.5 Areas with high potential for high-tech greenhouse production in Kentucky (green areas have the highest potential)

Figure 3.5 shows that a large part of Kentucky has favorable conditions for establishing greenhouse structures. The eastern part of Kentucky appears to have fewer favorable conditions for the development of greenhouses. In this region AppHarvest started its first greenhouse in Morehead in the Appalachia region. The planned greenhouses of AppHarvest in Richmond and Berea are better situated with respect to aspects assessed in this study.

The results of Global-Detector do not include the availability of labor. The availability of labor is illustrated here separately by the unemployment rate (see Figure 3.6). Figure 3.6 shows that Eastern Kentucky offers good opportunities due to the higher unemployment rate than in other parts of Kentucky. Job creation was one of the reasons for AppHarvest to start a greenhouse operation in Morehead. Jobseekers are willing to work in greenhouse horticulture, according to various sources in the state and region. Most workforce in greenhouses (about 90\%) is needed for crop, harvest and sorting work. The estimated labor need of a year-round culture of tomato, peppers or cucumbers lies between 6,100 and 8,500 hours/ha (or about 3.5-5 fulltime workers) for cultivation work and about 550 hours/ha for management activities (Ruijs and Benninga, 2020). 


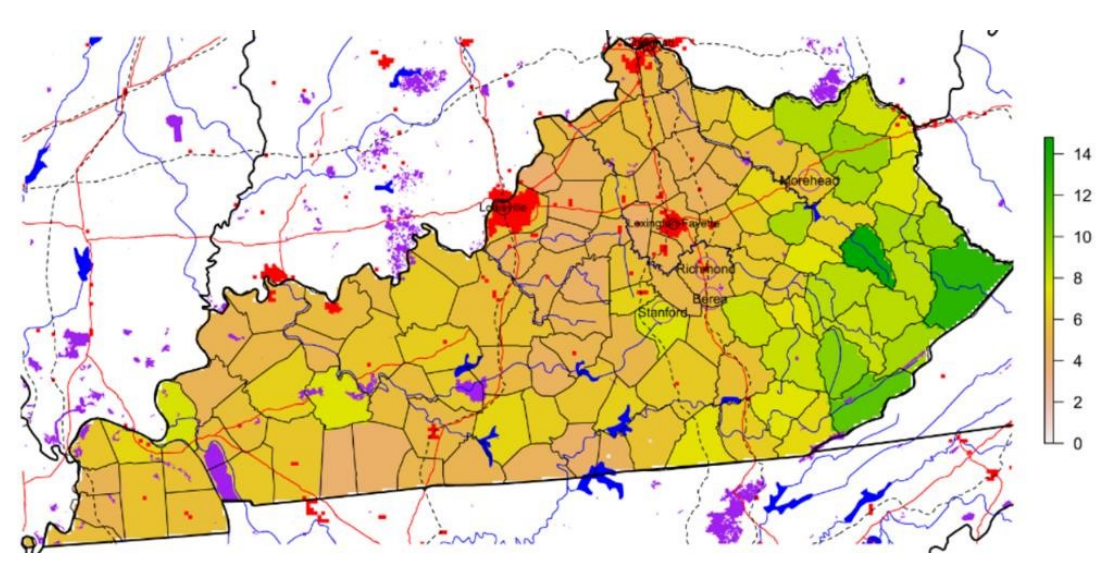

Figure 3.6 Unemployment rate per county in Kentucky in (December 2020; in \%)

A few remarks about the results of Global-Detector:

- Calculations for suitability are based on a limited set of selected indicators (publicly available worldwide data, plus data for energy production for Kentucky)

- Results should be used as a first step in the search for potential regions

- In a second step, a potential region should be investigated further with other detailed data and additional information (e.g. development restrictions by local government). Such information is not integrated via Global-Detector.

\subsection{Project-based location}

The suitability of land for greenhouse horticulture will also have to be viewed from the perspective of a project-based location or an individual location. A project-based location is usually intended for several greenhouse horticulture companies. In addition, other (horticultural-related) companies (within and outside the value chain) can be involved in the developments. A project-based location requires an area with a certain minimum size (e.g. $>200$ ha), good cooperation between public and private parties, and a long lead time. This applies in particular to the realization of collective sustainable facilities with regard to energy, water and infrastructure, e.g. collective rain water storage, collective cleaning of drainage water, sustainable energy sources like solar, geothermal, and biomass energy, heat and $\mathrm{CO}_{2}$ networks with other industries, collective waste, recycling and logistics services, etc. An individual location concerns a smaller-scale development of greenhouse horticulture (areas).

Realization of premises of an individual location is often easier and faster; however, the realization of collective sustainable facilities is less simple or possible, but creates more possibilities for sustainability.

Based on the available global information, the most suitable areas for greenhouse development appear to be in Central Kentucky.

\subsection{Next steps}

Although many areas seem suitable for greenhouse horticulture, the following elements should be considered in the search for most suitable areas for greenhouse production and/or AgTech Ecosystem development:

1. The green-colored areas in Figure 3.5 appear to be suitable for high-tech greenhouse production. Nevertheless, more detailed data and information will be needed to determine the right combinations of greenhouse production and energy and water supply. Most promising renewable energy sources are hydro, biomass and solar. Where are the best options for co-location with renewable energy and $\mathrm{CO}_{2}$ delivery? 
2. Global-Detector looked at a grid-level of $2.5 \times 2.5 \mathrm{~km}^{2}$ ( $=625 \mathrm{ha}$ ). The question arises from different sides as to whether a smaller area can be suitable for greenhouse development. Further (technical) research should be done to find out the minimum size of sustainable greenhouse development. A main factor is whether greenhouse development is intended for a project-based location or for an individual location.

3. The availability of labor or workforce should also be considered in the following step. Figure 3.6 shows the unemployment rate as an indicator of labor availability. Eastern Kentucky offers good potential, because job seekers are willing to work in horticulture and are also willing to accept a 1-hour travel time to work (info Kentucky stakeholders). For other 'green-colored' regions, the availability of labor needs to be further analyzed. How can the labor need in the short-term be filled with (skilled) employees? Are immigrant laborers needed?

4. Suitable areas for AgTech Ecosystem development not only depend on the suitability for greenhouse production, but also on the presence of logistics hubs and other economic sectors. Other economic sectors have not been included in Global-Detector. It is to be expected that hubs and other economic sectors will be located around larger cities and along roads or railroads. Where are industry clusters present that can enhance AgTech Ecosystem development?

5. The advantages of sustainable production in relation to project-based location in the state of Kentucky: collective sustainable facilities with regard to energy, water and infrastructure, e.g. collective rain water storage, collective cleaning of drainage water, sustainable energy sources like solar, geothermal, and biomass energy, heat and $\mathrm{CO}_{2}$ networks with other industries, collective waste, recycling and logistics services, etc.

Further research needs to be carried out to look at potential co-locations with companies in the value chain (packaging, input suppliers, etc.) and outside the value chain (waste valuation, exchange of energy, food processing, etc.). Based on best practices in the Netherlands the following recommendations can be made. Locations where companies are established which can supply (renewable) energy (e.g. power plants (rest heat), hydroelectric plants and solar) or can exchange energy (e.g. datacenters) are the first to come into the picture for co-location with greenhouse horticulture. Subsequently, it concerns locations with logistics companies.

Good locations can certainly be found in Central Kentucky, where energy suppliers and logistics companies are already located. 


\section{$4 \quad$ Results definition phase}

In this chapter the results of the market and chain analysis, technical analysis and governance aspect will be discussed.

\subsection{Market and value chain}

In this section the focus is on the market and value analysis of fresh greenhouse products.

\subsubsection{Current situation}

In the US the consumption of fresh vegetables per capita (about 154 pounds) is more or less stable in the period 2016-2019. From 2000-2015 it was at a slightly lower level (about 145 pounds). ${ }^{3}$ The consumer interest in sustainability is still growing in the US. ${ }^{4}$ This also includes the demand for fresh fruit and vegetables.

Kentucky's location relative to consumer conglomerations is favorable: within an 800-km radius (day trip for a truck) is two-thirds of the US population in an area between the Gulf of Mexico, the Great Lakes, and the East Coast. This will increase the potential to reach (new) markets. Within this radius, there will always be competition from other US states and Canada in the North American market (see Figure 4.1). Recently, new high-tech greenhouses have been built in these states, such as the company Pure Flavor with locations in Michigan, Georgia and Texas, ${ }^{5}$ company Pomas Farms Inc. in Ontario, Canada ${ }^{6}$ and the company Mastronardi Produce. ${ }^{7}$ These and other expansions indicate that there is still room on the market for high-quality greenhouse products.

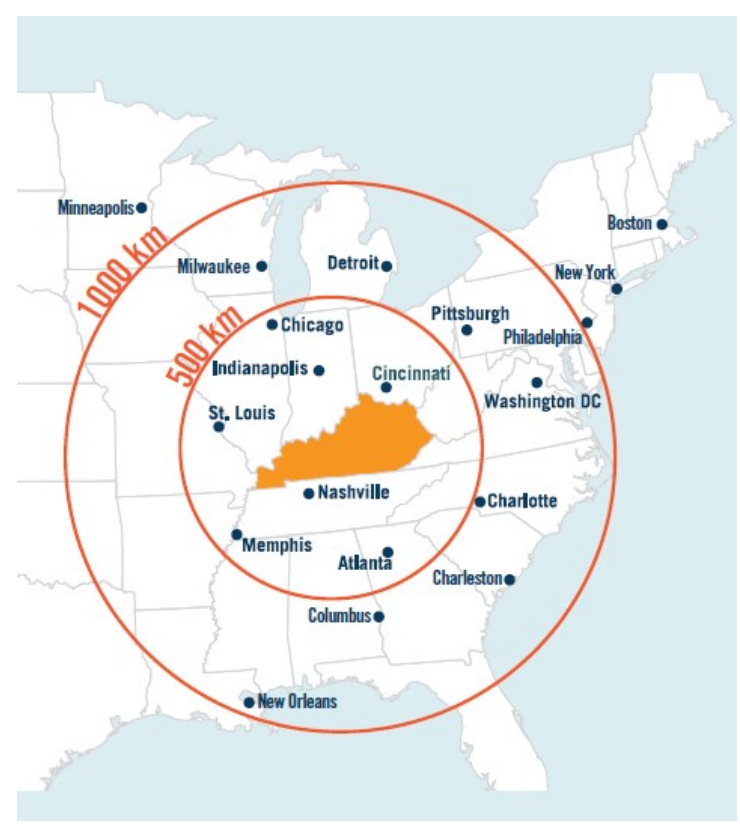

Figure 4.1 Kentucky's position in the US Source: Team Kentucky, Cabinet for Economic Development, 2017. Brochure Just the facts: Logistics and Distribution.

3 www.statista.com

4 https://www.foodbusinessnews. net/articles/17988-consumer-interest-in-sustainability-is-still-growing

5 https://www.pure-flavor.com

6 https://www.groentennieuws.nl/article/9307618/pomas-farms-kan-gaan-telen-in-grootste-kas-van-noord-amerika/

7 https://www.groentennieuws.nl/article/9167899/de-omvang-van-dit-project-is-enorm/ 
Building up the supply chains, contracting, and long-term sales agreements with wholesalers or retailers is a point of attention. For which market(s) products are produced and to which wholesaler(s) or retailer(s) the products are supplied.

AppHarvest is currently focusing on fresh vegetables and fruits. The greenhouse operation in Morehead, Kentucky started in January 2021 with the first produce (beefsteak tomatoes and tomatoes on the vine) in its history. The products are sold to one wholesaler and are destined for one retailer. Plans are made for production locations in Richmond (fruits and veggies) and Berea (leafy greens). These greenhouse operations will be the start of production in the short to medium term. The produce is intended to be sold to grocery stores and restaurants. ${ }^{8}$

AppHarvest and the Commonwealth of Kentucky have the ambition to expand AgTech in the state. As such, AppHarvest is actively searching for new locations. AppHarvest will possibly focus on other products and/or markets. It is up to AppHarvest itself which products it will select. Market demand is an important factor in this.

Given the high-tech greenhouse development, it seems logical to focus on high-value speciality products for high-end markets to earn back the investments. On the other hand, the product itself will require different types or differently equipped greenhouses because of specific crop requirements.

When we look in a broader perspective of AgTech development, the type of greenhouse structure and degree of technology will not be identical everywhere due to differences in crops and local situations.

This may offer opportunities for other growers than AppHarvest to produce other products for different markets. This could mean that mid-tech greenhouses could also be part of AgTech Ecosystem development. This could suggest an expansion of the consortium.

Moreover, not every consumer is willing to pay or can afford high-priced high value products. Do commodities have prospects within the AgTech ecosystem development? And do these commodities meet the same sustainability requirements, or is a lower but minimum level of sustainability required (at least the legal requirements)?

\subsubsection{Next steps}

The following steps can be taken to anticipate changes in the AgTech ecosystem development and changes in the market for greenhouses products:

1. Explore new products and markets.

Which type of high-value products are promising within the AgTech development in general?

Besides fresh fruit and vegetables, attention can be paid to floral products, mushrooms, microgreens and other products such as protein products. Also, processed fresh food such as ready-to-eat soups and juices can be a market opportunity.

Elements of the exploration are complementary fresh vegetables and fruits for (high-end) markets, the location of consumer hubs, and the market channel.

2. Asses chain partners and consider a way to cooperate.

How do chain actors, such as wholesalers and retailers, cooperate with producers and how in the American market structure? Does this mean collaboration with a selected group of partners in the chain (closed chain), or different partnerships with companies (open chain)?

To form a counterforce to the market bargaining power of the large trading/wholesale companies and large-scale retail, producers must join forces: you are vulnerable in the market if you stand alone. To this end, in the Netherlands, almost all fruit and vegetable producers are members of market associations. These associations bundle supply, sell through various forms of contracts (multi-year, year, month, day), and add value (through packaging, etc.). These market associations also collect information about the expectation of the harvest in the coming weeks, so that they can adapt their sales strategy accordingly. It is a point of interest in Kentucky to see if and what form of market association is useful. And also the wholesaler and retailers could be involved in the AgTech Ecosystem development.

8 www.appharvest.com 
3. Explore the perspectives of other commodity products in addition to high-value products Besides high-value products also commodity products might be part of the produce of an AgTech ecosystem. For example to reach (local) consumers who cannot afford high-value products. These commodities should at least meet the minimum required level of sustainability. This can also include products produced in a mid-tech greenhouse. For example, soft fruit, such as berries, which used to be grown outdoors and which have undergone a development towards protected cultivation in the last ten years.

\subsubsection{Remarks}

In general market research is the responsibility of commercial companies. AppHarvest has done market research for their own products and markets. Market research on new products is also useful input for the design of the appropriate greenhouse production system.

From an AgTech Ecosystem development view, market and chain analysis is interesting for other product-market combinations and broadening of the market for other producers. The government is also interested in which other producers and products could be part of the AgTech Ecosystem development.

In this context, a next step in market research is interesting for the Kentucky government, but for AppHarvest it does not seem to be the top priority.

\subsection{Technical aspects of greenhouse production}

\subsubsection{Current situation}

\section{Technology}

Greenhouses come in different shapes and sizes. A commonly used typology is a distinction between low-tech, mid-tech and high-tech greenhouses. Low-tech are plastic greenhouses with passive climate control. Mid-tech greenhouses have usually plastic structures with limited environmental control. Hightech greenhouses have mainly glass structures with a high degree of active environmental control and automation. These differences are illustrated in Figure 4.2.

The greenhouse production facility of AppHarvest in Morehead is categorized as 'high-tech.' It uses modern greenhouse technologies to realize a high productivity and quality level in a sustainable way. High-tech greenhouses are also planned for the locations in Richmond and Berea. Additional expansion is foreseen.

Another high-tech greenhouse in Kentucky is that of Kentucky Fresh Harvest in Stanford. This is a controlled environment agriculture project producing tomatoes on several acres. It uses a closed loop drip irrigation system in which the water that the plants do not use is recaptured, cleaned and recycled. For year-round production Kentucky Fresh harvest uses a combination of LED and HID lighting to facilitate growth. The fresh products go to the domestic market. ${ }^{9}$

Looking to the future, which conditions and greenhouse technologies will be needed in the short and medium term to improve viability and sustainability of the desired greenhouse production system? What steps can be made in the field of energy consumption, reduction of carbon dioxide emissions, and use of crop protection agents and fertilizers? The options for energy and water supply also depend on regional availability. As discussed in the spatial analysis, the main energy resources are currently hydro and biomass along with solar. Geothermal energy seems less potential as energy source for greenhouse production in Kentucky, because it has the lowest class indication (see chapter 3 ). The main water supply for plant production is from rain and some additional from rivers and lakes. Aquifers are not homogenous across the state and need to be considered regionally (Personal communication University of Kentucky). Use of groundwater and aquifers is not considered

9 https://www. kyfreshharvest.com 
sustainable. This can change if the surplus rainwater can be temporarily (= season) stored in aquifers (when suitable). In dry periods, this water can be pumped up and used in the greenhouses. In Dutch greenhouse areas rainwater storage in aquifers is very common (Van Wijk, 2020). This usually happens collectively. From an environmental point of view, in the Netherlands it is already mandatory from 2010 for greenhouse horticulture companies to have a water basin of at least $500 \mathrm{~m}^{3} / \mathrm{ha}$.

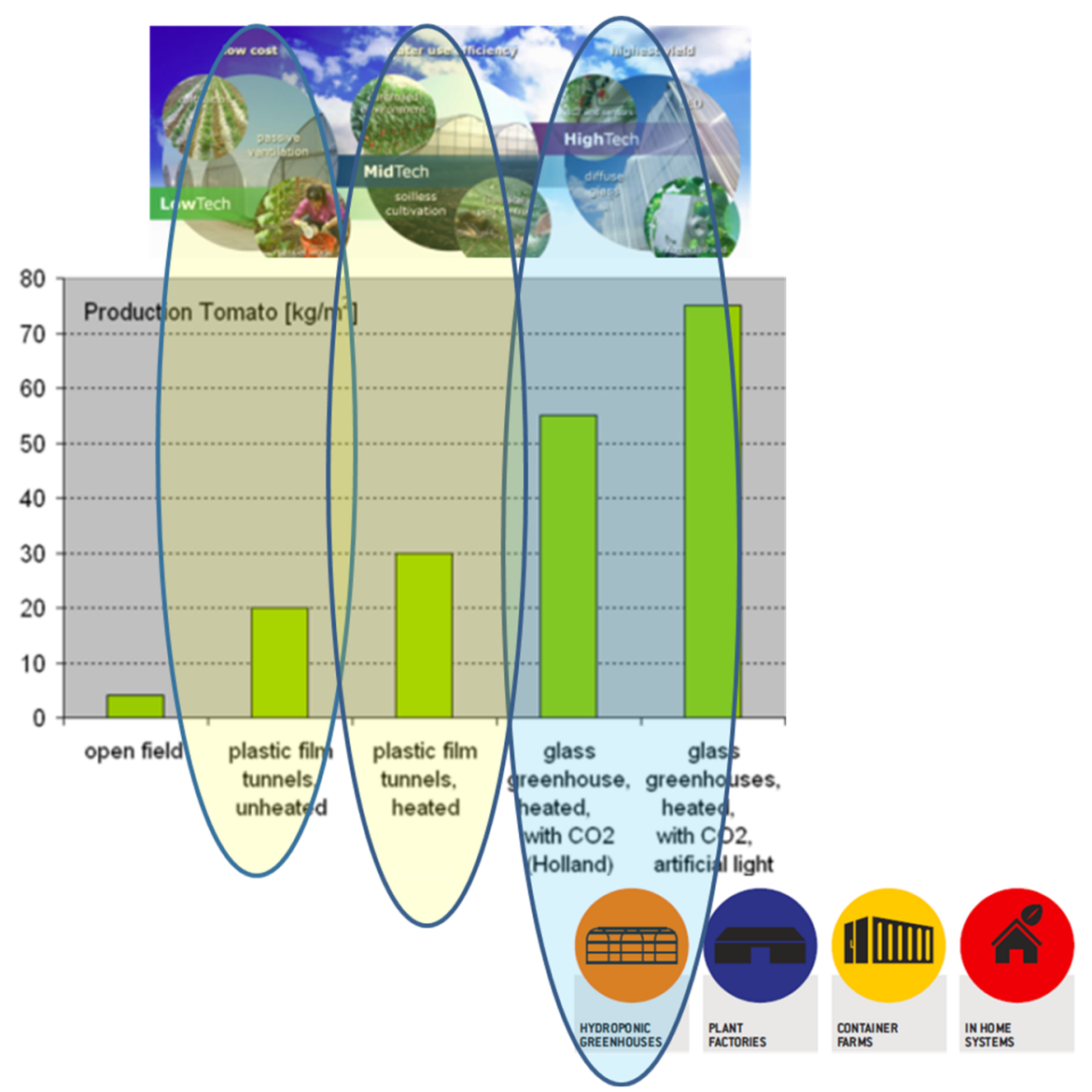

Figure 4.2 Technology level of greenhouse production systems Source: Info WPR/BU Greenhouse Horticulture (Ruijs, 2018).

Reducing or adding value to waste flows, such as packaging materials and organic material, has ongoing attention. An example is the processing of tomato fibers. Some initiatives have resulted in high quality paper (e.g. Schut Papier BV). ${ }^{10}$ Other applications, such as clothes, are still in development or in a start-up phase. ${ }^{11}$

There are different types of high-tech greenhouses, but the differences are not so great that there is an advantage for a specific type for suitability in areas where building land is scarce, such as urban areas or hilly and mountainous areas. Vertical farming, which needs less space, has received a lot of attention in recent years. There are many initiatives worldwide, ${ }^{12}$ but not all have proven themselves commercially.

Although the focus of this research is on high-tech greenhouses, are there also possibilities for midtech greenhouses which can meet the sustainability requirements to a large extent? This offers opportunities for producing commodity products for consumers who cannot afford high-value products. Mid-tech greenhouses have limited environmental control, especially regarding climate control, compared to high-tech greenhouses. However, mid-tech greenhouse are not specifically the focus of Dutch businesses. It is worthwhile to investigate further for which products or product types mid-tech

\footnotetext{
10 www.schutpapier.nl

${ }^{11}$ e.g. https://www. biophilica.co.uk/

12 www.vertical-farming. net
} 
greenhouses might be suitable (see also Section 4.1). An example of these products are soft fruits, such as blue and raspberries.

\section{Knowledge and education}

Besides technology, knowledge and skills are very important to achieve the potential of a network of greenhouse production systems. Against this background, it is necessary to educate and prepare young people for a career in greenhouse horticulture for the 'ecosystem' concept to reach its potential. At this moment, five US colleges and universities in Kentucky are involved in the collaboration agreement, which is signed by 17 consortium parties (see Appendix 1). Together with the Dutch educational institutions in the consortium, they will develop education programs at different levels of education and for different subjects. These subjects concern agriculture/horticulture, supply chain logistics and management. Vocational-level discussions are ongoing to exchange knowledge and students between Kentucky and The Netherlands. A Memorandum of Understanding (MoU) for collaboration has already been signed between universities in Kentucky with the Dutch Applied University HAS Den Bosch on plant production. Another MoU is in preparation between universities in Kentucky and the Dutch Applied University of Fontys with regard to supply chain and logistics.

In the short term, workforce training is needed to carry out the activities in the current and planned AppHarvest greenhouses. In that context, AppHarvest engaged the Dutch organization Hortitech (one of the members of the World Horti Center in the Netherlands), who is in conversation with Lentiz and Priva Academy about a training program to quickly train people in cultivation and management (leadership).

Greenhouse horticulture development also offers opportunities for US companies to become potential business partners for Dutch greenhouse suppliers, such as supplying materials for greenhouse structures or substrates for cultivation systems. This cooperation can be shaped in various ways (see chapter 5).

\subsubsection{Next steps}

In principle, the approach towards sustainable greenhouse production follows the adaptive greenhouse concept. The design of the greenhouse will be determined by local conditions such as climate, the presence of (natural) sources, socio-economic aspects, and legislation (Vanthoor et al., 2007).

The following subjects can be mentioned for further research:

1. Analyze which (new) technologies and partnerships might give additional support to sustainable production

This refers especially to the topics of energy, crop protection, and fertilizers because of their environmental impact. New technologies include hardware, such as installations, but also software, which supports the efficient use of the hardware. In particular, the digitalization of the production process can contribute to this.

- Energy options:

- Use of rest heat from power plants, chemical industry, biomass and/or datacenters, mostly delivered to a cluster of greenhouse companies. This option is successfully implemented in The Netherlands for example in the greenhouse areas 'Oostland' (Van Wijk, 2020) and 'AgriportA7' (AgriportA7, 2020; see Figure 4.3). This option could also include energy sharing between data centers and greenhouse companies (AgriportA7, 2020). 


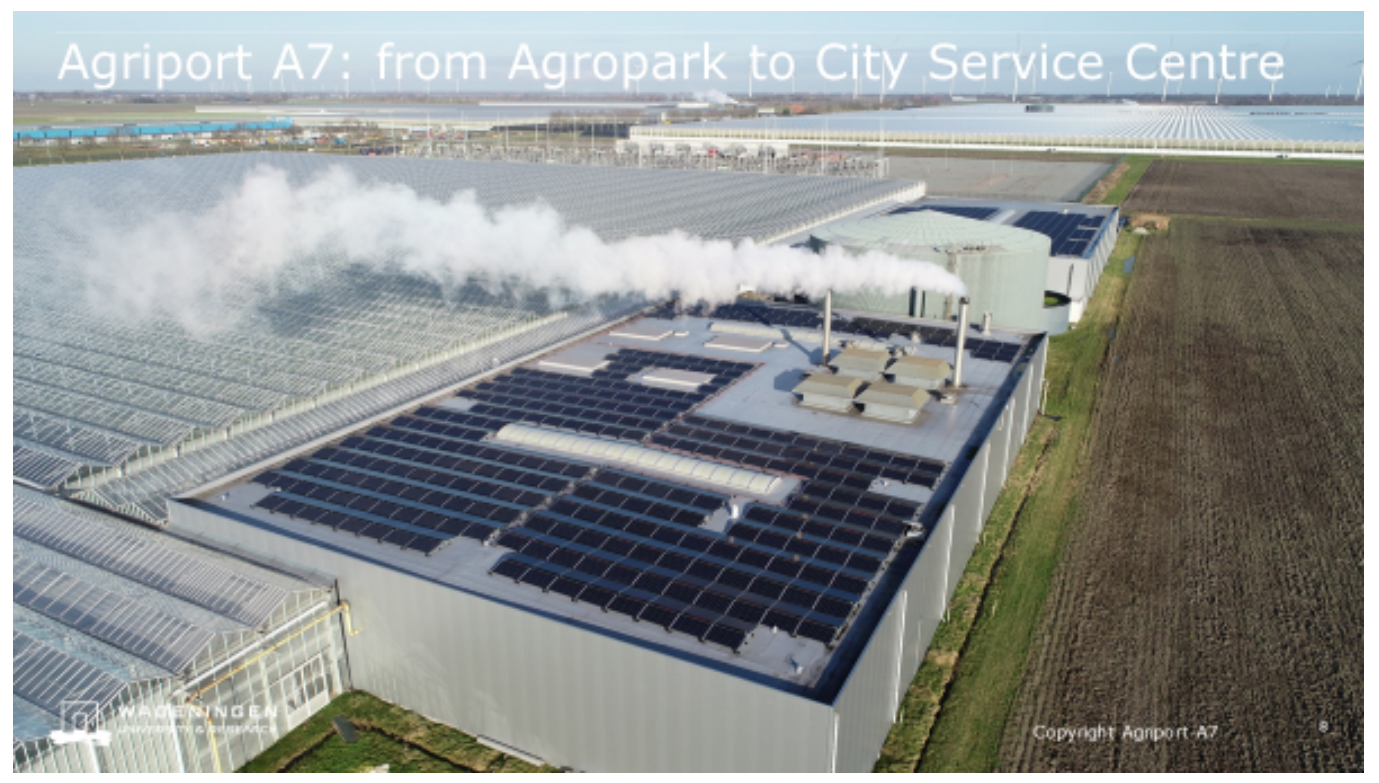

Figure 4.3 AgroportA7 (NL); energy exchange between greenhouses and other industries Photo (C)Agriport A7.

- Use of carbon dioxide from (gas burned) power plants, mostly delivered together with rest heat to a cluster of greenhouses. Successfully implemented in the 'Oostland' area (Netherlands); see Figure 4.4 .

\section{Residual $\mathrm{CO}_{2}$ network}

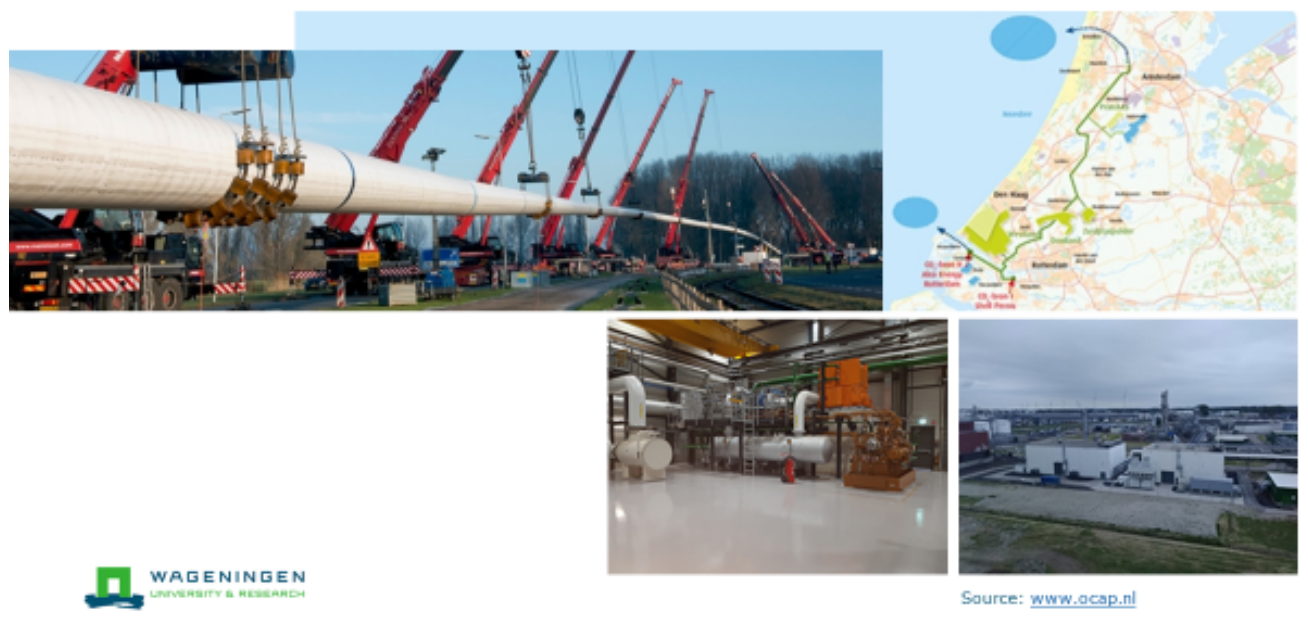

Figure 4.4 Residual CO2 network form power plant (OCAP)

Photos (C) OCAP (www.ocap.nl).

- Use of electricity from solar and wind farms. The electricity is delivered to the public grid.

- Use of green gas from biomass via a biodigester. The green gas is delivered to the regional gas network. Successfully implemented in 'NEXTgarden'13 in the Netherlands (see Figure 4.5).

13 www.nextgarden.nl 


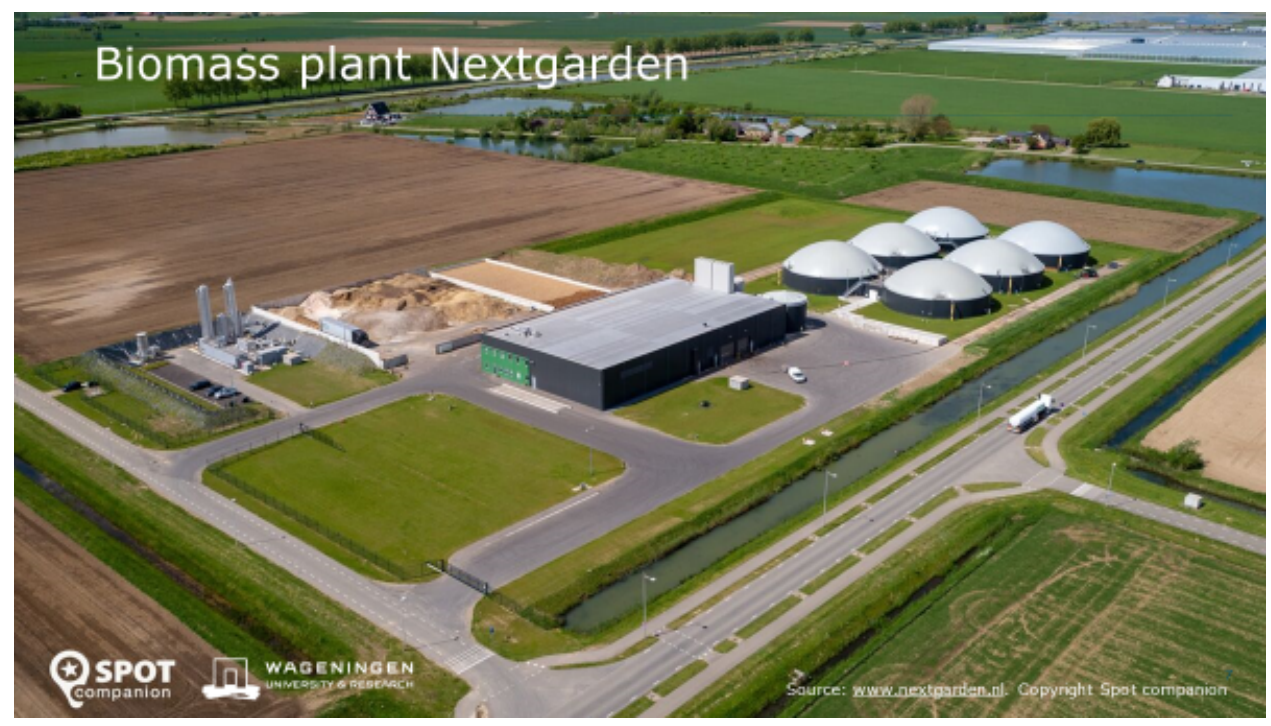

Figure 4.5 Green gas from biomass in NEXTgarden (NL) Photo @ SPOTCompanion.

- Use of geothermal energy seems to have low opportunities in Kentucky, but is worth investigating because of the successes in the Netherlands (in 'Oostland' and 'Westland' area (see Figure 4.6); Van Wijk, 2020).

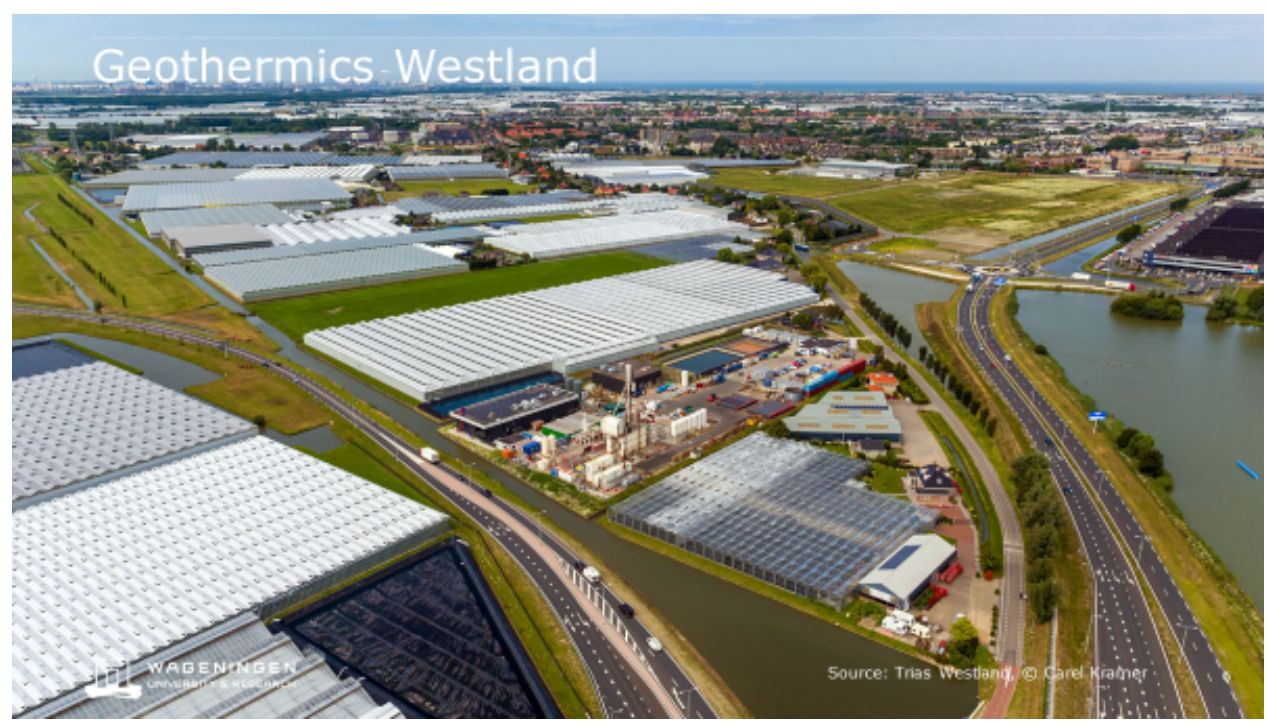

Figure 4.6 Geothermal energy in Westland (NL)

Source: Trias Westland, Photo (c) Carel Kramer.

This analysis should be combined with the spatial analysis regarding the availability of (renewable) resources and potential co-location.

- Energy saving technics, such as energy screens, highly insulating greenhouses and dehumidification. These options can be implemented at farm level.

- Energy saving management: the next generation cultivation. This includes energy-efficient cultivation and optimal production at the same time. Already implemented in practice in The Netherlands, but still in research and development. ${ }^{14}$ Courses were organized to educate the growers.

14 www.kasalsenergiebron.nl/besparen/het-nieuwe-telen 
- Integrated pest management:

- In addition to biological control the replacement of chemical crop protection products by less harmful products.

- Intensive scouting and monitoring (with drones).

- Nutrient management:

- Use of water retaining, re-using, storage and filtration options at farm level to achieve a high water use efficiency. The need for local/regional options will be greater when the greenhouse area grows to a larger scale. An example is the collection of rain water in combination with floating solar panels; NEXTgarden (NL); see Figure 4.7.



Figure 4.7 Rainwater collection and floating solar panels in NEXTgarden (NL). Photo (C) SPOTCompanion.

- Waste valuation:

- Waste products, such as tomato fibers, can be processed into package materials and clothes. Some initiatives have resulted in high quality paper (e.g. Schut Papier BV) ${ }^{15}$ or packaging material. ${ }^{16}$ Other applications, such as clothes, are still in development or in a start-up phase. ${ }^{17}$

- Contribution of artificial intelligence and robotics to climate control and crop management for efficient use of inputs and better harvest prediction.

- Data driven growing, using crop models (e.g. Letsgrow) ${ }^{18}$

- Deleafing robots (info Priva);

- Internal transport robots

- Sorting and packing machines

- Etc.

- Which options are best for employing smart logistics. This includes for example a combination of different and sustainable transport options and use of ICT (for tracking \& tracing among other things).

\footnotetext{
15 www.schutpapier.nl

16 https://duijvestijntomaten. nl/verpakken/

17 e.g. https://www.biophilica.co.uk/

18 https://www.letsgrow.com/en/news/moving-towards-data-driven-growing/
} 
2. Analyze if mid-tech greenhouses would have added value within the AgTech Ecosystem development

With mid-tech greenhouses, the AgTech Ecosystem could provide consumers with a wide variety of fresh produce at different prices. It is likely to contribute to an increase in food security.

- Do mid-tech greenhouses offer a broader range of options for new companies and create more diversity in jobs? Study which producers of greenhouse products would be interested in participating in the AgTech Ecosystem development. These producers usually operate small or medium-sized midtech greenhouses and produce for the local and regional market.

- Might a combination of high-tech and mid-tech greenhouses initiate additional activities and other supporting industries? Research among the supply chain parties whether a combination of high-tech and mid-tech greenhouses could create new business.

3. Study what type of knowledge creation (education level, disciplines and skills) is needed concerning greenhouse production (cultivation and management) and the supply chain (logistics and management)

In principle, all levels of education should be included in the study, from vocational to master's degrees. Different actions with respect to education are in motion across Kentucky and Dutch education institutions.

- As already mentioned in the short-term, education and practical training of people are needed to carry out the activities in the greenhouses. This could include practice-oriented courses.

- In the mid-term, training and education on the vocational level is needed. This could be a basic education with additional training in practice (hands-on experience). The Dutch vocational school Lentiz has already been asked by AppHarvest for a proposal. One of the questions is which knowledge and skills will be part of the basic education. Although this is primarily in the interest of Appharvest, it is also valuable for other greenhouse farms.

- What education is already present at Kentucky colleges and universities? This question should also be answered against the background of remote control of greenhouses. Will these education modules be developed separately or incorporated into existing training courses of colleges and universities?

- In the mid and long term, education and training should be set up on all levels (vocational and academic) and focus on different topics, such as plant production, climate control, pest management, technical aspects, postharvest and waste management. Dutch education institutes can help Kentucky colleges and universities to develop and adjust their curriculum and their way of working to the needs of the private sector. Exchange of students and staff could be part of the collaboration. This collaboration will be further worked out by the Kentucky and Dutch education institutes.

- In addition, to educational development, research activities can also help further develop the AgTech Ecosystem. AppHarvest has the ambition to set up a research facility in which improved or new techniques and methods can be tested and then implemented. In the first instance, it probably concerns practice-oriented research and will focus on crop management, climate control, integrated pest management and nutrient management (see above under point 1). Both Dutch (such as HortiTech (partner of the World Horti Center) ${ }^{19}$ and WUR Greenhouse Horticulture ${ }^{20}$ and Kentucky (research) parties can support this development.

Remarks:

- The need for (higher) education and training and research activities will be greater if and when the greenhouse horticulture sector grows (rapidly) in size.

- Financing will also be an important aspect. Should it be publicly and/or privately funded? Currently financing of education and training is done separately. It can be investigated whether co-financing is useful for which levels and subjects.

19 www. worldhorticenter.nl

20 https://www.wur.nl/en/Research-Results/Research-Institutes/plant-research/greenhouse-horticulture.htm 


\subsection{Governance \& design ecosystem}

\subsubsection{Current situation}

In 2020, a collaboration agreement was signed between 17 US (Kentucky) and Dutch private and public partners. Dutch partners will help and/or facilitate the US partners in realizing their AgTech Ecosystem and in turn benefit from the knowledge exchange with US partners.

The following points can be taken into account in the further development of the AgTech Ecosystem:

First, it is noticed that the involvement of Kentucky/US private sector is limited. Until now, only AppHarvest represents the US private sector. The Dutch private sector is well represented by horticultural suppliers. There is already outside interest in the consortium and requests from (US) parties how and when they can join (Info NLWorks). Further growth of the consortium can be beneficial for all participants. According to the outline of governance structure, admittance of new members is possible but subjected to guidelines.

Private companies from the supply chain will likely be interested to take part in the ecosystem development. When the production sector expands to at least 200 ha (about 500 acres) of greenhouses, as experience in the Netherlands showed, then other supply chain companies will follow and will establish in the area (Buurma and Ruijs, 2011; Agriport A7, 2020). ${ }^{21}$ This includes companies from the packaging and logistics sector and input suppliers. The combination of the production sector and other supply chain companies can evolve into a so-called 'agro-cluster' or, in the case of Kentucky, an AgTech Ecosystem. For the strength of an agro-cluster (or ecosystem) to be realized, the production sector is essential (Berkhout et al., 2015).

Besides AppHarvest, Kentucky Fresh Harvest (Stanford), ${ }^{22}$ another high-tech greenhouse operation is present in the state. Kentucky Fresh Harvest is also focusing on producing fresh vegetables and, in particular, tomatoes. As Berkhout et al. (2015) has concluded, it would be relevant to the interests of other greenhouse producers to join the AgTech Ecosystem development. The production sector could then increase in size and economic importance and will attract other companies from the complete supply chain: from seed to consumer. Examples are:

- Seed and seedling companies

- Supply industry: nutrients, chemical and biological crop protection agents, substrates, small equipment, etc.)

- Technical companies: greenhouse design, climate control, water, light, heating and cooling techniques, internal transport, mechanization and robotization, sorting, etc.

- Packaging providers

- Logistics companies

- Organic waste management, recycling of substrates, etc.

- Food processing (fresh ready-to-eat salads, juices).

In the Netherlands, the composition of the greenhouse horticulture areas differs. This is partly historically determined. The older areas, such as Westland/Oostland, Aalsmeer and Venlo, are examples of a more complete cluster or ecosystem. In the new(er) areas, such as AgriportA7, Nieuw Prinsenland, NEXTgarden and Biopark Terneuzen, in addition to greenhouse horticulture companies, in particular, companies are located that supply (sustainable) energy and water. A logistics company is present in some areas (e.g. AgriportA7).

For more information about the Dutch greenhouse areas, see:

- Westland/Oostland https://greenportwestholland.nl/en/

- Aalsmeer: http://greenportaalsmeer.nl/

- Venlo: https://greenportvenlo.eu/

- AgriportA7: https://www.agriporta7.nl/

21 https://nieuwprinsenland. nl/glastuinbouwlocatie/locatie/

22 www. kyfreshharvest.com 
- Nieuw Prinsenland: https://nieuwprinsenland.nl/?lang=en

- NEXTgarden: https://www.nextgarden.nl/

- Biopark Terneuzen: http://www.bioparkterneuzen.com/en/biopark.htm.

The newer areas can serve as an example for the AgTech Ecosystem development in Kentucky. It is recommended to take note of this in a follow-up study.

A study by Buurma and Ruijs (2011) showed that a bottom-up approach (i.e. AgriportA7) was more successful than a top-down approach (i.e. NEXTgarden). In the bottom-up approach, the private sector was in the lead, while in the top-down approach, the initiative was taken by the government. In a bottom-up approach, government cooperation is of course required (e.g. spatial planning). This point deserves attention in the AgTech Ecosystem development in Kentucky.

A second point about the role the Kentucky government can play in driving the development of the AgTech ecosystem is the development of expertise. The interviews revealed that there is currently limited government knowledge and expertise at all levels to support the development of an AgTech Ecosystem. This refers to land use requirements, education and legislation. Regarding land use requirements, new knowledge creation and thought leadership is needed around what changes can be made to the permitting, building and zoning of greenhouses. These changes should support the sustainable development of the AgTech Ecosystem. Such measures will stimulate the sustainable growth of the ecosystem. In this respect, experiences in the Netherlands are useful to consider in reviewing which measures could be effectively applied in the Kentucky situation. This could include stimulating co-location, stimulating or demanding (to some extent) use of renewable energy, demanding clustering, stimulating re-use of waste streams, etc. The government can stimulate by adapting spatial and environmental legislation, investing in infrastructure, financing workforce development, etc. It is recommended to take note of the development of the greenhouse horticulture areas in the Netherlands, in particular the new(er) greenhouse horticulture areas (see above). The contribution of the Dutch government lies mainly in specifying the legal frameworks for sustainable development and providing fiscal advantages and subsidies, in particular for renewable energy, to accelerate sustainable development. The legal frameworks have been drawn up in consultation with the sector.

Regarding education, the Kentucky government can support (by funding) colleges and universities to develop curricula or education programs to help accelerate the development of an AgTech Ecosystem. The interviewed stakeholders indicated that education and training are the most important factors in supporting and accelerating AgTech Ecosystem development.

A third point is whether societal groups should be involved in the AgTech ecosystem development. The involvement of societal groups can be useful for support in the transition process. An example is the support of the Dutch environmental movement for the concrete plans of the sector organisation Glastuinbouw Nederland to create an energy transition including geothermal energy, residual heat, energy savings and electrification. According to some consortium members, societal groups should be informed about the AgTech Ecosystem development. This can be done regularly, when there is reason to do so. These societal groups could (also) include farming communities, the Kentucky Horticultural Council, Master Gardner Program in Kentucky and some livestock groups (interested in sustainable development). These groups can add value in telling the story and interesting others in the AgTech Ecosystem development.

\subsubsection{Next steps}

The following steps can be mentioned for further research:

1. Study which new members (companies) could be of added value to the consortium and ecosystem.

In general, new members will be admitted when they add value and broaden the consortium and the AgTech Ecosystem development. This refers to companies both inside and outside the supply chain. 


\section{Examples of companies within the supply chain:}

In the first phase, production facilities have to be built and equipped. That requires the involvement of the (technical) supply industry. For example, construction companies can assist in the development and erection of high-tech projects.

As mentioned before the production sector is essential for the strength of a cluster or Ecosystem development. Other producers, such as Kentucky Fresh Harvest and any others that are attracted to the Commonwealth of Kentucky, will strengthen the Ecosystem development. It is recommended to actively approach other growers to participate in the ecosystem development.

Another category of companies are the seed and seedling companies. In a follow-up study several (domestic) companies can be approached to gauge their interest. Rijk Zwaan, as a consortium member, would be one of them.

Packaging companies and logistics companies are also worth the effort to determine their interest. Kentucky has several logistics companies, such as Amazon, UPS and DHL, with established operations. This is because of Kentucky's strategic location. About two-thirds of the U.S. population is within a day's drive of Kentucky. A future collaboration of AppHarvest with a logistics company seems very logical, as long as they are equipped or willing to become equipped to transport fresh products to different markets such as retail, groceries and restaurants. Shipping of fresh products are mostly done by specialized transporters who can condition the airflow during transport (the 'cold chain').

Examples of companies outside the supply chain:

Energy or utility companies are important sectors to engage to strengthen the ecosystem. For example power plants, hydro-electric and biomass companies. They can deliver (rest) heat, electricity, $\mathrm{CO}_{2}$, etc. to greenhouses. This can also entail engaging companies from other industries producing residual heat. Delivery of $\mathrm{CO}_{2}$ will become more important when renewable energy, such as biomass, is the main energy source.

Another cluster of companies to collaborate with is the food and beverage sector, especially companies with which fresh vegetables from greenhouses can be combined in the market approach. Most greenhouse products are sold and shipped directly to the market, except pre-cut vegetables such as lettuce and other leafy greens. Lower grades products might be upgraded to high-value products, such as soups, juices, sauces, etc.

Industry that can use waste streams such as organic material to make new products reflect another opportunity. Some of these products may be re-used in greenhouse production such as packaging material and substrate. For example biobased packaging based on tomato fibers. ${ }^{23}$

Companies from the tech sector are also interesting partners. Concerning high-tech greenhouses, artificial intelligence (in greenhouse control) and automation and robotization are special fields of interest. At least one of the consortium members has plans to set up a service location in Kentucky.

When looking for other parties or companies to help strengthen the AgTech Ecosystem development, it is important to determine what the mutual benefits and potential of a collaboration might be. A good approach is to ask what industry is already present at a specific location, and how could it help the AgTech Ecosystem grow or become more sustainable.

As a general recommendation, further research is needed as to which companies and institutions will be joining the AgTech Ecosystem development and can play a beneficial role in its sustainable development. Various companies already have shown their interest (known by the consortium).

\section{Governance model:}

When the AgTech Ecosystem grows in terms of number of participants, the question will be whether the governance structure in Figure 3.6 is equipped for this. What is a good governance model, and

\footnotetext{
23 https://duijvestijntomaten.nl/verpakken/
} 
could the Greenport model from the Netherlands (Greenports Nederland) ${ }^{24}$ be useful for this after adaptation to the American situation?

Greenports Nederland is a national partnership between business, government and knowledge institutes. In this strategic network, the business community (auctions, trading houses, exporters, horticultural suppliers, financial and advisory institutions), interest groups, governments and knowledge organizations work together to collectively strengthen the horticulture sector. Focus areas are: labor market and education, energy, healthy plants and healthy people, innovation, spatial design, internationalization and fresh logistics. ${ }^{25}$ In a follow-up study it is recommended to investigate if and how the Greenport model might be a model structure for Kentucky to mobilize toward. In this follow-up, attention should be paid to the differences between the Netherlands and Kentucky/US with regard to the investment climate and way of doing business. In the US, companies are more competitive than collaborative compared to the Netherlands (Personal communication University of Pikeville). Therefore other governance models might be more suitable.

\section{Greater role of Kentucky government}

The Kentucky government must play a supporting and stimulating role in the transition towards a sustainable AgTech Ecosystem. First, the government can adapt or revise existing legislation and regulations to promote sustainable greenhouse production. This refers to the permitting, building and zoning of greenhouse areas. For example, governing bodies may make regulatory adjustments or recommendations with respect to land use and building requirements (for example maximum heights of greenhouses and company shed and required reduction of emissions to water, soil and air (light, nutrients, pesticides and $\left.\mathrm{CO}_{2}\right)$ ). The government can also help by investing in common infrastructure (such as energy supply), with subsidies for the use of renewable energy, etc.

In addition, the government can support education and training programs to help increase the level of knowledge and competencies. This appears to be very relevant because in many places there is a lack of knowledge and expertise.

- Further study is needed to indicate which specific changes could be made to the permitting, building and zoning of greenhouses based on the experiences in the Netherlands. Which changes could be effective and adapted to the Kentucky situation.

- These changes are related to project based locations and individual locations. Examples from the Netherlands can be used to view the application possibilities. In that context, it is possible to look at the new(er) greenhouse horticulture locations, such as AgriportA7, Nieuw Prinsenland and Biopark Terneuzen, and how the legal framework has been designed (e.g. spatial planning and sustainability and building requirements).

- Further research is also needed to find out in what way the government can support education (e.g. funding of colleges and universities).

- This concerns the short, medium and long term.

- On different subjects, such as plant production, pest management, technical aspects, postharvest, waste management and location aspects.

- Examples of education and training programs are the agricultural education system in the Netherlands and the Mexican research, knowledge and training institute Ceickor.

The first example refers to the Dutch Triple Helix model, the cooperation between government, businesses and knowledge institutes (Geerling et al., 2017), and the Agricultural Knowledge and Innovation System/AKIS (see Figure 4.8).

\footnotetext{
24 www.greenports-nederland.nl

${ }^{25}$ www.greenports-nederland.nl
} 


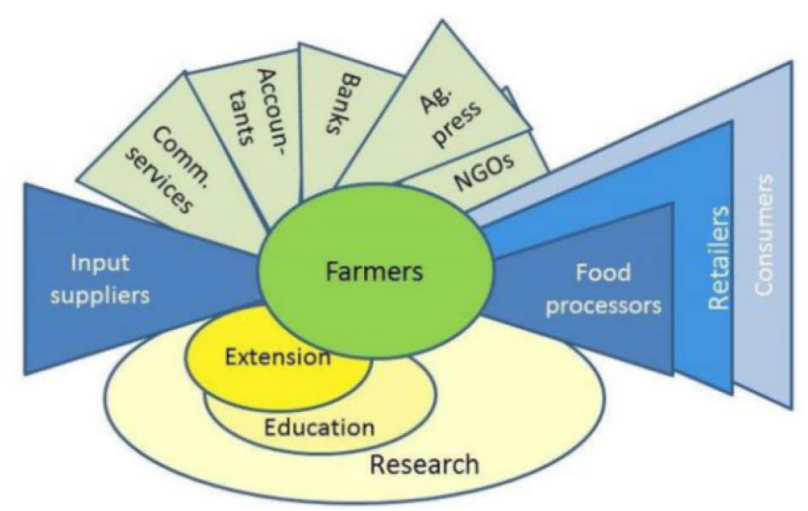

Figure 4.8 Visualization of the Agricultural Knowledge and Innovation System Source: SCAR-AKIS.org.

Ceickor is an example of a research, knowledge and training institute in Mexico and has experience with professional training programs and applied research and advises local producers and workers about the cultivation and technical operation of greenhouses. Since 2020 there is a collaboration between World Horti Center, Ceickor and Koppert Biological Systems. World Horti Center and Ceickor are business-driven initiatives. ${ }^{26}$

In a follow-up study the aim is to assess how the Triple Helix model and AKIS can be applied to the Kentucky situation.

- Within the government, too, an increase in knowledge and skills is needed to support the development of AgTech Ecosystems

- To be a good discussion partner for the horticultural industry, qualified people are needed to be able to assess requests related to AgTech Ecosystem development.

3. Explore how societal groups should be involved in the AgTech Ecosystem development This step should indicate in what way societal groups can be involved in the transition process (organizational and role). Social groups can play an important role in achieving common goals and meeting the demands of society, the environment, the market and the surrounding area. This concerns, among other things, achieving sustainable spatial and economic development.

An example is the role of an environmental group in the integration of greenhouse horticulture in the rural environment of AgriportA7 (Agriport A7, 2020). One of the agreements between societal groups and the project organization Agriport A7 was how the greenhouses can be more hidden from view.

\subsection{Potential barriers and opportunities for Dutch and Kentucky businesses}

The Dutch greenhouse supply industry can play an important role in the development of the AgTech Ecosystem in Kentucky based on their experiences in the past and present. The Dutch government, through NL Works and RVO, plays a supporting role in this and is closely involved in the developments in Kentucky.

Most experiences are related to high-tech greenhouse development worldwide. The foundation Dutch Greenhouse Delta, with representatives from the Dutch greenhouse supplying industry, 'promote the Dutch horticultural sector worldwide and focus on complex, large-scale projects concerning food and floriculture issues in growing megacities'. ${ }^{27}$ In addition, some Dutch companies build mid-tech (plastic) greenhouses for customers. Depending on the customer's wishes, the Dutch greenhouse builders not

${ }^{26}$ https://www. koppert.com/news/mexican-ceickor-world-horti-center-and-koppert-sign-mou/

27 https://www.dutchgreenhousedelta.com/ 
only take care of the design and construction of the greenhouses, but also services (such as training and cultivation management) can be organized in the form of a full service contract.

The Dutch greenhouse supply industry has global experience, but there may still be some obstacles or barriers hindering their operations in Kentucky. There are also opportunities.

Also, for Kentucky/US businesses the AgTech Ecosystem development can offer opportunities. This includes companies inside and outside the supply chain.

\subsubsection{Potential barriers}

An initial barrier is the unfamiliarity of Dutch companies with local circumstances. There is not enough local Dutch presence and Dutch companies are unknown to Kentucky partners. Building trust is more challenging currently because of the COVID-19 situation.

A cultural mindset also plays a role. There remains some hesitation among certain groups in Kentucky related to issues of climate change and food shortage.

\section{Legal aspects}

Current legislation and regulations with regard to land use and building requirements can be an obstacle, because it is not adapted or revised to the needs of a sustainable greenhouse development. More information (such as dimensions and innovative technologies) from greenhouse designers is needed about crucial elements of the building process to help the Commonwealth of Kentucky with revising regulations (see also Section 4.3).

\section{Competition of domestic and foreign companies concerning greenhouse projects}

The Dutch greenhouse industry is not the only one that builds greenhouses. Other companies from Canada, Israel, France, etc. can be serious competitors. This depends partly on the level of the technology to be used.

On the other hand, feeding (mega)cities is worldwide an important theme these days. So other countries are also developing AgTech ecosystems, which the Dutch greenhouse horticulture supply industry can focus on.

The AgTech Ecosystem development can offer various opportunities for Dutch and US companies to support and facilitate this development.

\subsubsection{Potential opportunities}

- In general the opportunities for Dutch and Kentucky companies are almost unlimited. Food security and security of supply of fresh products play an important role in this. It depends on the speed and dimension of the development of the AgTech Ecosystem whether opportunities will become reality.

- There are many opportunities for Dutch and Kentucky companies within and outside the value chain (see also Section 4.3).

Within the value chain, this refers in the first place to Dutch greenhouse suppliers (construction and installations), input suppliers (e.g. seed and substrates) and service suppliers (consultancy, training and courses). This can result in new businesses and new partnerships with US companies (agents, joint ventures, etc.). For example, labor for building greenhouses is already being provided by US partners, and collaborations have been created between Dutch and U.S. greenhouse builders

An approach to make this more concrete is to analyze the development process in the new glasshouse horticultural areas in the Netherlands. How did this process go and which parties and types of companies played an important role in it. In a follow-up study this could be carried out in the form of case studies with the question of what and how this translates to the situation in Kentucky. 
- There are opportunities for US companies to supply input materials to Dutch greenhouses constructors.

For example: steel and aluminum. The general tendency is to build greenhouses and equipment using locally available materials. Dutch companies are in this context responsible for the greenhouse design and supervision of the building process.

The digitalization (the use of digital information and devices) offers possibilities for Dutch service suppliers to give advice and training remotely in the field of crop management, climate control and integrated pest management.

With respect to the development of a Kentucky HortiCenter (KHC), with focus on demonstration and practical research, Dutch companies can contribute to Ecosystem establishment and implementation. Dutch companies can demonstrate their products and/or conduct research to adapt their technologies to local circumstances.

In the field of logistics and packaging, there are options for US companies, in particular when it supports the AgTech Ecosystem development. This refers for example to sustainable ways of transport and the supply of sustainable or biobased packaging materials.

Outside the value chain, there are many options for US companies regarding renewable energy sources (rest heat, hydro-electric, biomass and solar), waste management, biobased products and new food (food processors). Especially providers of renewable energy will contribute to the success of the AgTech Ecosystem development.

More or less the same approach can be followed as with companies within the horticulture supply chain. In fact, it can be a combined study to determine the business opportunities. 


\section{Conclusions and recommendations}

\section{$5.1 \quad$ Conclusions}

\subsubsection{Spatial analysis}

Much of Kentucky appears to be suitable for greenhouse production. Only the Eastern part seems less suitable, but the availability of labor is more favorable. Additional analysis will be required to determine the types of supporting activities that are more suitable for the Eastern region or the infrastructure needed to connect labor in this region to other more favorable AgTech Ecosystem activities. Viewed from various location factors, Central Kentucky appears to be the most suitable location for AgTech Ecosystem development and in particular if project-based establishment is being pursued.

For a project-based establishment of greenhouses and related (chain) activities, a minimum area size of 200 ha (about 500 acres) is needed. Individual establishment of a greenhouse offers more possibilities to find a suitable location, but the subsequent realization of collective sustainable, supporting facilities becomes more difficult.

\subsubsection{Market and chain analysis}

Kentucky's location relative to consumer conglomerations is favorable: two-thirds of the US population is within an $800-\mathrm{km}$ radius (day trip for a truck). The rising demand for fresh vegetables in the US and recent expansions of greenhouse horticultural establishment in the US and Canada indicate that there is room on the US market for high-quality greenhouse products. Building up the supply chains, contracting and long-term sales agreements with wholesalers and retailers are points of attention.

The AgTech Ecosystem development is based on high-tech greenhouse production. This vision maintains that high-value products will have the main focus. There is a wide range of products that qualify for this, such as fruits, vegetables (premium products of tomato, sweet pepper, cucumber, eggplant), specialties, microgreens and even ornamental products.

Nevertheless, it makes sense to explore the possibilities of mid-tech greenhouses and associated products. One of the products is soft fruit, such as berries. This product is grown at different levels of technology (from outdoor till high-tech). This may offer diversity in jobs and might attract other producers to join the AgTech Ecosystem development.

\subsubsection{Technical analysis}

The development towards an AgTech Ecosystem requires a sustainable approach to production. In this context, future use of renewable energy sources will be crucial. Biomass and small hydroelectric are the main renewable energy sources along with solar. Unfortunately, there seems to be less potential for geothermal energy in Kentucky. With an increasing use of renewable energy, the needed supply of $\mathrm{CO}_{2}$ will become more essential.

Other topics in the transition towards an AgTech ecosystem development are the application of integrated pest management, water and nutrient management, waste valuation and other technologies, such as ICT and robotics.

To achieve the potential of high-tech greenhouse production education and training of employees, staff and students is very important. In the short-term practical training is needed, while on the medium- and long-term education on all levels should be developed in fields such as crop 
management, climate control, integrated pest management, nutrient management, logistics and waste management. Dutch organizations are already involved in some initiatives for the short-term.

\subsubsection{Governance}

A governance structure has already been made for the Kentucky AgTech consortium. This governance structure is temporary and will eventual transfer into a legal entity (as mentioned in the collaboration agreement).

To strengthen the AgTech Ecosystem development, the consortium can be expanded with (Kentucky/US) companies which add value or broaden the activities. This refers to companies within the horticulture value chain, such as production, logistics and packaging companies. Outside the horticulture value chain, it refers to providers of renewable energy, waste valuation companies and the food industry.

A greater role of the Kentucky government is suggested. The government can play a supporting and stimulating role by creating the preconditions for sustainable greenhouse production. On the one hand the government can revise regulations for permitting, building and zoning of greenhouse establishments and areas, while on the other hand it can stimulate by investing in infrastructure and collective energy and subsidizing the use of renewable energy.

The government can also play an important role in supporting (funding) education and training at colleges and universities and in other educational initiatives.

\subsubsection{Potential opportunities and barriers for Dutch and Kentucky/US companies for doing business}

There are plenty of opportunities for Dutch and US companies in doing business related to AgTech Ecosystem development. Dutch greenhouse input and service suppliers can benefit from the AgTech Ecosystem development. On the US side, companies in and outside the value chain may benefit when they support or strengthen the ecosystem development. This refers to companies in the field of logistics, packaging, energy supply, waste management, robotics and food processing.

Important barriers for Dutch companies to do business are the current regulations with respect to greenhouse development and the unfamiliarity of Dutch companies with the Kentucky situation and culture.

\subsection{Recommendation for follow-up research}

This inception study provides a basis for a follow-up study to better assess the feasibility of the intended AgTech Ecosystem.

The recommendations are aimed at realizing a cluster with greenhouse horticulture and other (horticulture-related) business activities. Based on experiences in the Netherlands and in other countries and the interviews the following prioritization of recommendations has been made.

\section{Education and training}

Education and training of employees and staff in greenhouses and related horticultural chain activities will have the highest priority.

- In the short term, Dutch-US collaborations should focus on knowledge transfer via education and practical training for greenhouse employees. This could include development and implementation of a practice-oriented course (hands on training). AppHarvest has asked the Dutch vocational school Lentiz to set up a training in collaboration with Koppert Biological Systems and Priva.

- In the mid-term, training and education on the vocational level is needed. This could entail a basic education and training in practice. This education and training could be developed separately or incorporated in an existing program or course of a college. The subjects depend on what is missing, 
but in general this includes various subjects related to high-tech production. In this respect the Dutch HortiTec was asked by NWorks to conduct a study to design a Kentucky HortiCenter, in which this education and training will be part.

- In the mid and long term, education on all levels from vocational to academic degree programs is needed, spanning different subjects in the value chain (e.g. crop management, climate control, pest management, waste management, logistics and chain management). In this perspective also research and best practices will be a basis for developing curriculum and educational pathways. In a follow-up study the Dutch Triple Helix model and the Agricultural Knowledge and Innovation System (AKIS) can be used to determine which education programs and research activities can be developed.

2. Governance - actors and model structure

- With regard to governance, one of the points of attention is which parties can add value and/or broaden the activities of the AgTech Ecosystem. This refers to companies within the value chain, such as production, logistic and packaging companies. Outside the value chain it refers to providers of renewable energy, waste valuation companies and the food industry.

In a follow-up study, companies can be questioned that have already shown their interest. In addition, parties can be approached that are seen as essential from the perspective of AgTech Ecosystem development.

- In line with the previous point, which governance model is most suitable for this objective in the long term? Could the Dutch Greenport (network) model serve as a basis (not a blueprint) for adapting to American circumstances?

The Dutch Greenport model and other governance models could be taken into account in a follow-up study.

- A greater role of the Kentucky government is mentioned with regard to supporting the establishment of greenhouses and providing horticultural (related) education. Spatial, legal and financial instruments would form a good base for this. Further study should reveal exactly what this means in practice. For example, how should current regulations be amended with regard to the permitting, building and zoning of greenhouses.

In a follow-up study some cases of new horticultural areas in the Netherlands can be analyzed: how was the stimulation from the government organized, which instruments were used and what are the results. Pitfalls must also be included.

\section{Location/spatial analysis}

Central Kentucky appears to be the most suitable area for AgTech Ecosysteme development. Nevertheless, a more detailed study is needed to identify specific areas for project-based locations with colocation of greenhouses and other supporting sectors. With respect to project-based location, special attention should be paid to other activities inside and outside the supply chain, e.g. the location of other companies within and outside the chain located. In any case (renewable) resources, good infrastructure and workforce are important preconditions. A small number of sub-regions or counties (2-3) could be selected to gather more detailed data and information about the presence of or potential for supporting elements including renewable energy sources, water resources, infrastructure (connectivity to cities), logistic and packaging companies.

In a follow-up study, 2 to 3 cases of Dutch greenhouse horticulture development areas can be analyzed in the way they have developed over time. This concerns for example AgriportA7, Nextgarden and Nieuw Prinsenland. ${ }^{28}$ The successful development of AgriportA7 (bottom-up approach) is probably more in line with the American mentality of companies (competitive and win-win situation). Desired information includes: number, size (in acreage and production) and types of companies, order of establishment, time frame, etc. An earlier study was carried out for Agriport A7 and Nextgarden (formerly location Bergerden) by Buurma and Ruijs (2011). Recent information can be obtained through interviews with project developers and companies in the area. What information

${ }^{28}$ www.greenports-nederland.nl 
should be collected in Kentucky based on the case study in the Netherlands in addition to the data collected in the spatial analysis (Global Detector).

4. Technology analysis

Additional study is desirable to further improve the sustainability and viability of greenhouse production. Special attention should be paid to renewable energy sources and delivery of $\mathrm{CO}_{2}$. Integrated pest management, nutrient management, water management, waste management and waste evaluation must also be given attention.

In a follow-up study proven techniques and methods should be mapped out that could mean further development for current greenhouse horticulture in Kentucky. This first requires insight into the current techniques and methods at the production companies in Kentucky. This concerns energy configuration, energy consumption, water consumption, crop protection approach, handling of waste, etc. In some cases models (from WUR) are available to calculate energy consumption, for example, based on the needs of the cultivation, the available sources and the local climate.

In Section 4.2 some examples have been mentioned for inspiration.

5. Market and supply chain

Building up the supply chains, contracting and long-term sales agreements with retailers is a point of attention.

Although it has a lower priority it might be useful to explore the possibilities of mid-tech greenhouses and associated fresh horticultural products. Especially when other Kentucky producers would be interested. 


\section{References and websites}

Agriport A7, 2020. 15 jaar Agriport; Hier wordt gebouwd. Jubileum magazine 2020.

Anonymus, 2016. Understanding the AgTech Ecosystem. WPC document, 12 pp. (https://www.wpc.com).

Berkhout, P. et al., 2015. De kracht van het agrocluster; Het belang van de primaire productie voor het totale agrocomplex. LEI Report 2015-032.

Bone, G., 2020. Kentucky Energy Profile; 7th Edition • 2019. Kentucky Energy and Environmental Cabinet, Office of Energy Policy. Pp. 108.

Buurma, J.S. and Ruijs, M.N.A., 2011. Sustainable greenhouse horticulture and energy provision: two regional transition processes compared. In Transformation and sustainability in agriculture; Connecting practice with social theory. Vellema, S. (ed.). Wageningen: Wageningen Academic Publishers, p. 91-111 167 p.).

Geerling-Eiff, F.A., Hoes, A-C., and Dijkshoorn-Dekker, M. (2017). Triple helix networks matching knowledge demand and supply in seven Dutch horticulture Greenport regions. Studies in Agricultural Economics, 119(1), 34-40.

Hekkert, M.P., Suurs, R.A.A., Negro, S.O., Kuhlmann, S., Smits, R.E.H.M, 2007. Functions of innovation systems: A new approach for analysing technological change. In: Technological Forecasting and Social Change. Volume 74, Issue 4, May 2007, Pages 413-432.

Hennen, W.H.G.J., Daane, P.A.J., Duijvendijk, K. van, 2017. Global-Detector; GIS- and Knowledgebased tool for a global detection of the potential for production, supply and demand. In: Proceedings of the 3rd International Conference on Geographical Information Systems Theory, Applications and Management; Porto, Portugal, 27-28 April 2017. - : SciTePress - ISBN 9789897582523 - p. 161 - 168.

Hennen, W. and Ruijs, M., 2021. Suitability greenhouse investment in Kentucky; Spatial analysis with Global Detector. PPT document 13 April 2021, Wageningen Economic Research, The Hague.

Kuhlmann, S. and Arnold, E., 2001. RCN in the Norwegian Research and Innovation System. Background Report No 12 in the evaluation of the research council of Norway.

Ruijs, M., 2018. The global market size of greenhouse production, market trends and developments; Results 2017 - Background report. Wageningen, Wageningen Economic Research, Report 2018-113C. 26 pp.

Ruijs, M. and J. Benninga, 2020. Market potential and investment opportunities of high-tech greenhouse vegetable production in the USA; An exploratory study for Midwest and East Coast regions and the state of California. Wageningen, Wageningen Economic Research, Report 2020-054. 46 pp.

Smeets, P.J.A.M., Och, R.A.F. van, Cofino, M., Buijs, S. and Simons, A.E., 2015. Metropolitan Food Clusters and Agroparks: Designs and implemented examples. Alterra, Wageningen University \& Research Centre, Wageningen.

Team Kentucky, Cabinet for Economic Development, 2017. Brochure Just the facts: Logistics and Distribution.

Team Kentucky, Cabinet for Economic Development, 2020. Brochure Food and Beverage in Kentucky.

Vanthoor, B.H.E., Stanghellini, C., Henten, C.E. van, and E. Baeza Romero, 2007. De adaptieve kas: een generieke aanpak voor het ontwerpen van tuinbouw productiesystemen. (https://edepot/wur.nl/25731).

Wijk, K. van. (ed.), 2020. Werkboek Oostland; kansen voor de glastuinbouw in de gemeenten Pijnacker-Nootdorp, Lansingerland, Zuidplas en Waddinxveen. Uitgave gemeenten en provincie Zuid-Holland.

\section{Websites}

https://www.greenport-nederland.nl

https://www.appharbest.com

https://www.greenports-nederland.nl

https://www.kyfreshharvest.com

www.kasalsenergiebron.nl/besparen/het-nieuwe-telen 


\section{Consulted stakeholders and organizations}

Bianca Oudshoff, AppHarvest

Angelica Vega, Team Kentucky, Cabinet for Economic Development

Don Kester, Priva

Justin Lukoff, Certhon (till 1 June 2021)

Burton Webb, University of Pikeville. 


\section{Appendix 1 Kentucky AgTech Ecosystem Consortium Collaboration Agreement (signed by 17 parties)}

\begin{tabular}{|c|c|c|}
\hline Partner type & Kentucky/us & Dutch \\
\hline \multirow[t]{6}{*}{ Private } & AppHarvest & Dalsem \\
\hline & & Signify \\
\hline & & Priva \\
\hline & & Certhon \\
\hline & & Light4Food \\
\hline & & Rijk Zwaan \\
\hline \multirow[t]{5}{*}{ Education/Knowledge } & Berea College & HAS (Den Bosch) \\
\hline & Morehead State University & Fontys \\
\hline & University of Pikeville & \\
\hline & University of Kentucky & \\
\hline & Eastern Kentucky University & \\
\hline \multirow[t]{2}{*}{ Government } & Commonwealth of Kentucky & Dutch Ministry of Agriculture, Nature \\
\hline & & and Food quality (LNV) \\
\hline
\end{tabular}




\section{Appendix 2 Suitable greenhouse investments in Kentucky (Hennen en Ruijs, 2021)}

\section{Suitability greenhouse investment in Kentucky}

\section{Spatial analysis with Global-Detector, commissioned by NLWorks}

\section{April 2021, Wil Hennen, Marc Ruijs \& Peter Ravensbergen}
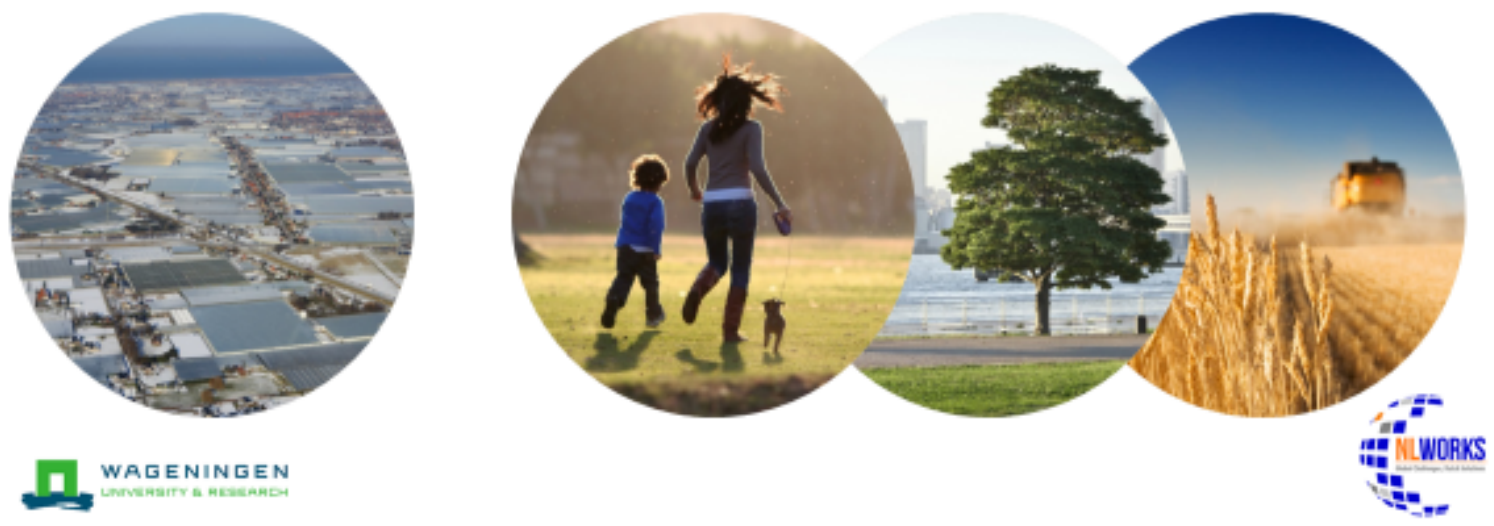

\section{Contents}

- Short introduction Global-Detector

- Selected indicators and parameter settings for aspects:

- Climate and water availability

- Infrastructure

- Land characteristics

- Energy

- Illustrations for Kentucky and, for the aspect 'Climate', a climate-suitability map for the USA

- Suitability (investment of greenhouses) map for Kentucky 


\section{Short introduction Global-Detector}

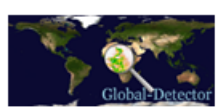

- The Global-Detector GIS tool combines a large amount of data at grid-level $(\sim 10 \times 10 \mathrm{~km})$ to estimate the suitability of regions e.g. for the production of specific crops. For this Kentucky study all data are converted to $2.5 \times 2.5 \mathrm{~km}^{2}$ [USA Contiguous Albers equal area projection]

- Grid-level data and experts knowledge are combined:

- Choose indicators and identify aspects (e.g. climate)

- Set minimal, optimal or maximum values

- Combine and weigh aspects and indicators

- Visually validate with experts joining

- Results vary depending on the model settings; weights given to indicators and aspects.

WAGENINGEN

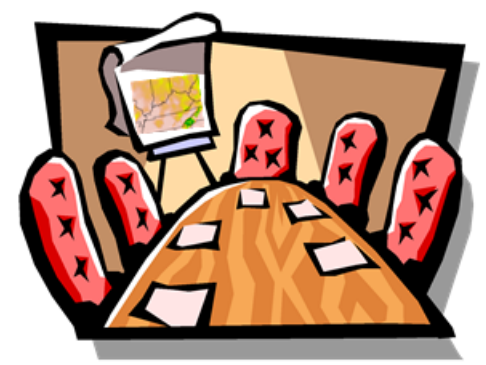

\section{Aspect Climate and water availability}

- Temperature

- Not too cold (avg. coldest month; $>-10^{\circ} \mathrm{C}$ and no restr. $>00^{\circ} \mathrm{C}$ )

- Not too hot based on the hottest month according to wet ball temperature (worse $>25^{\circ} \mathrm{C}$ and restr. $>30^{\circ} \mathrm{C}$ ) and difference between night and day temperatures in summer

- Water availability

- Yearly precipitation (above $1200 \mathrm{~mm}$ no restriction)

- Addition when shortage : rivers \& lakes and presence cropland

- Solar radiation (very low variation within Kentucky)

- Humidity (low weight; also small variation within Kentucky)

-Rigk afisea ow cover winter (some risk South-East Kentucky) 


\section{Aspect Climate and water availability USA}

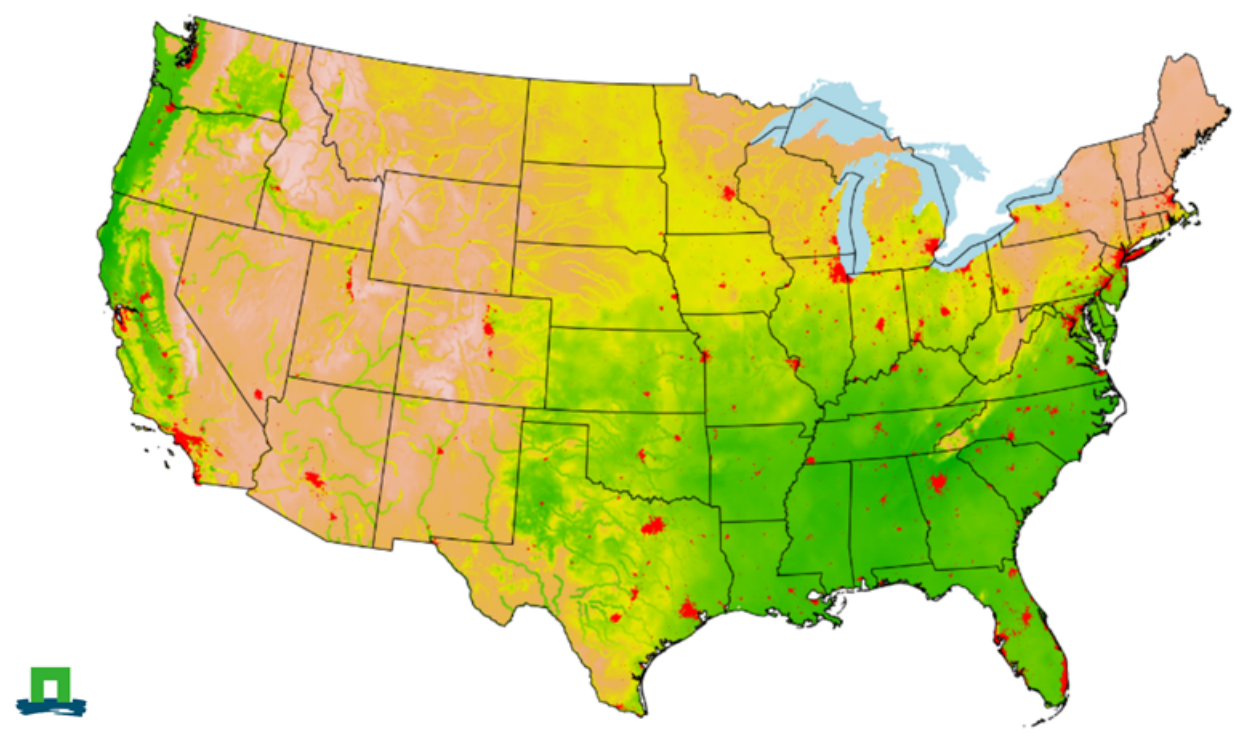

\section{Aspect Climate and water availability}

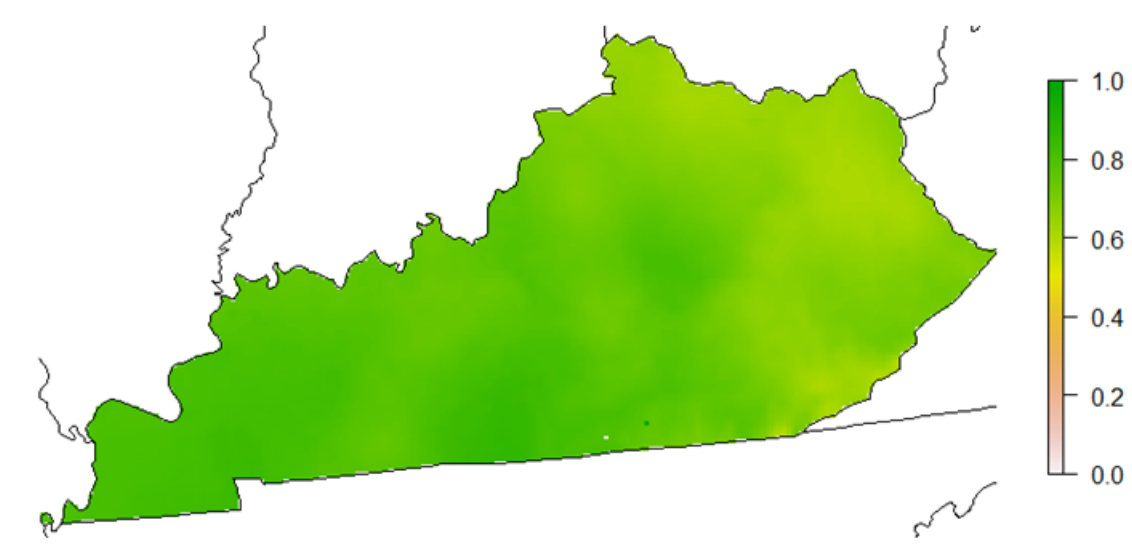

Remark: Climate and water availability has limited distinction in Kentucky 


\section{Aspect Infrastructure}

- Population near cities (for labour and short-chain markets)

- Population within radius of $500 \mathrm{~km}$ (marketing large range, 1 day)

- Travel time to cities (also for labour)

- Road density and quality

- Proximity of airports (very low weight)

- Availability of railroads (low weight)

\section{Aspect Infrastructure}



WAGENINGEN 


\section{Aspect Land characteristics}

- Not too much covered with forests (>75\%)

- Not too much covered with grassland (>75\%)

- Increasingly unsuitable if altitude $>500 \mathrm{~m}$; exclusion $>2500 \mathrm{~m}$

- Not too steep and excluded if grid average of slope $>20 \%$

- Exclusion if grid on water

- Increasingly unsuitable if population density $>250 / \mathrm{km}^{2}$; exclusion $>1000 / \mathrm{km}^{2}$

- Protected areas excluded (purple on map, not in model)

\section{Aspect Land characteristics}

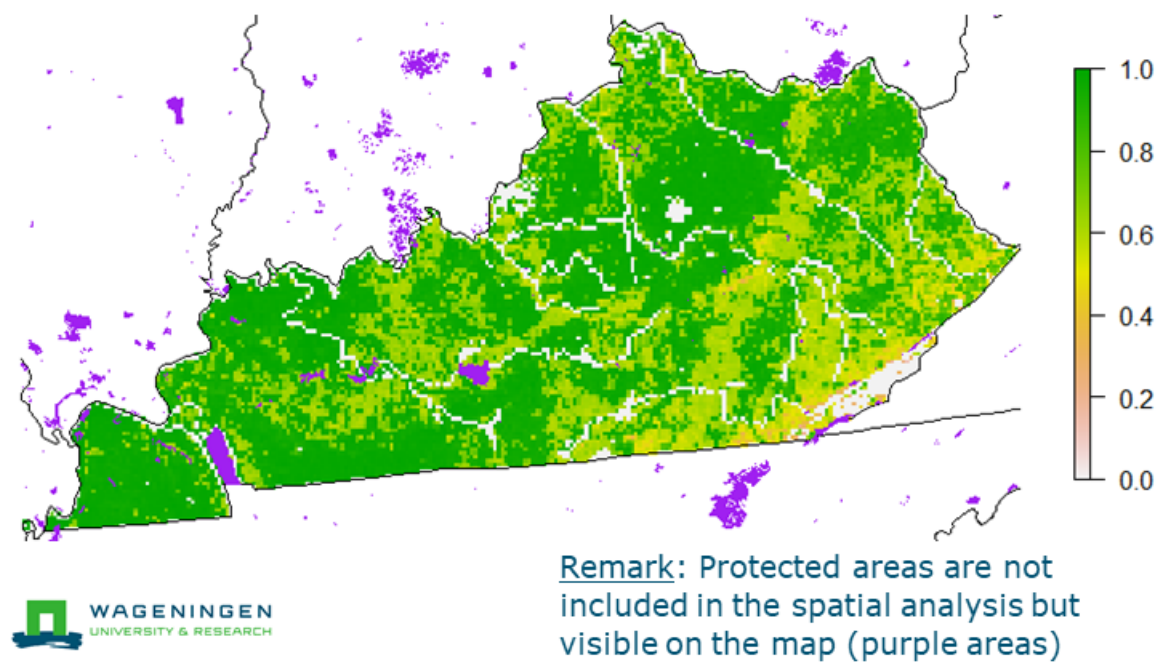




\section{Aspect Energy}

Sources provided by Kentucky government:

- https://maps.nrel.gov/re-atlas/

- https://www.eia.gov/maps/layer_info-m.php

- Power plants (buffers with capacity radius)

- Small hydro (buffers with capacity radius)

- Biomass (Biopower potential estimate based on available residue data, assuming conversion efficiencies between 30 and 35\%)

- Geothermal (in Kentucky predominantly lowest class (5))

- Solar photovoltaic (in Kentucky only small variation)

- Gas pipelines (buffer around pipes)

\section{Aspect Energy}




Suitability greenhouse production Kentucky



Extra restriction population density (excluded $>200 / \mathrm{km} 2$ )

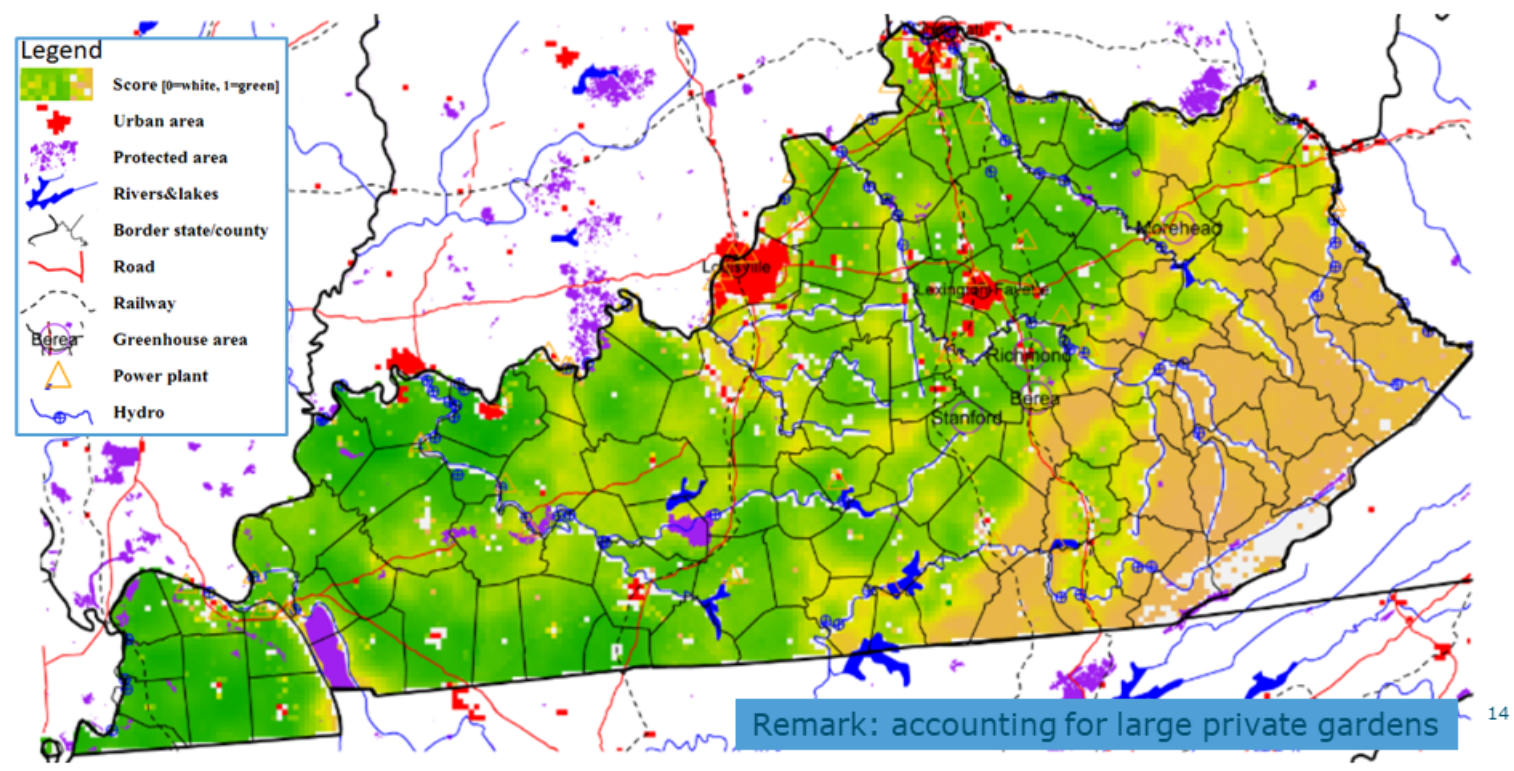


Suitability greenhouse production Kentucky

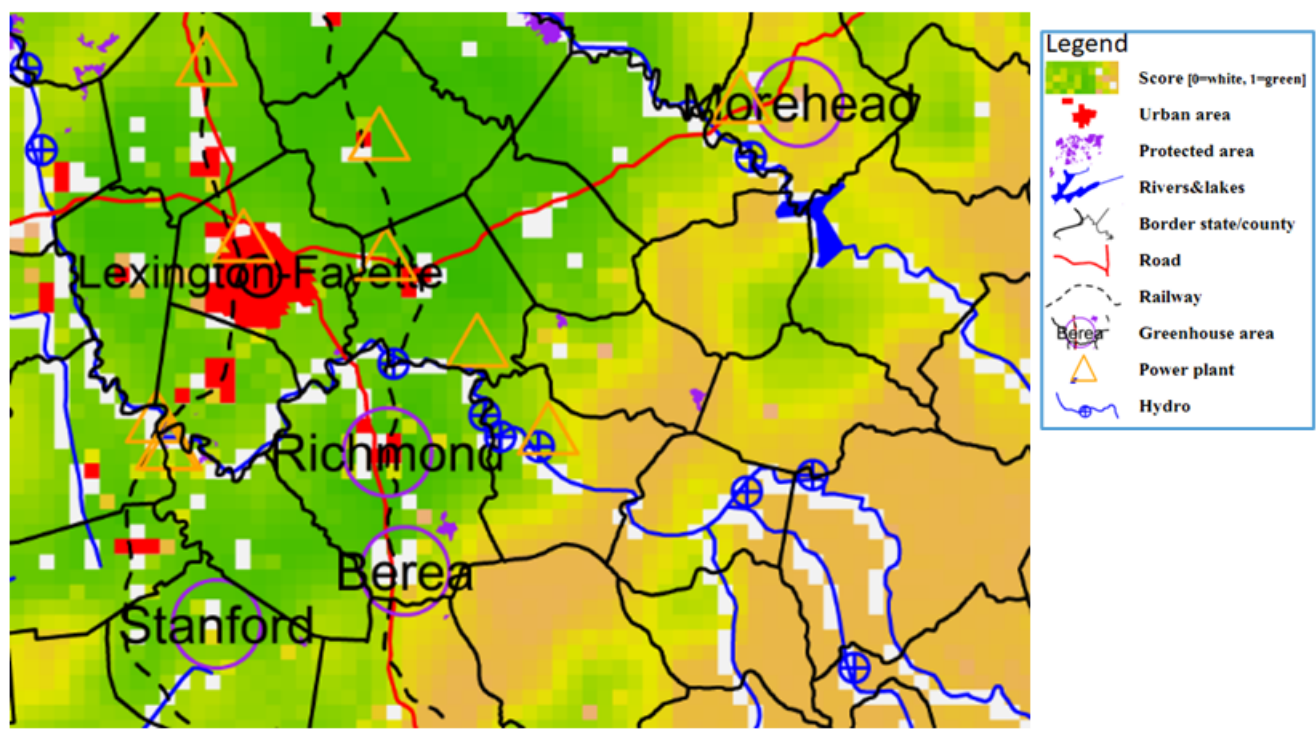

Unemployment rate per county (December 2020, \%)

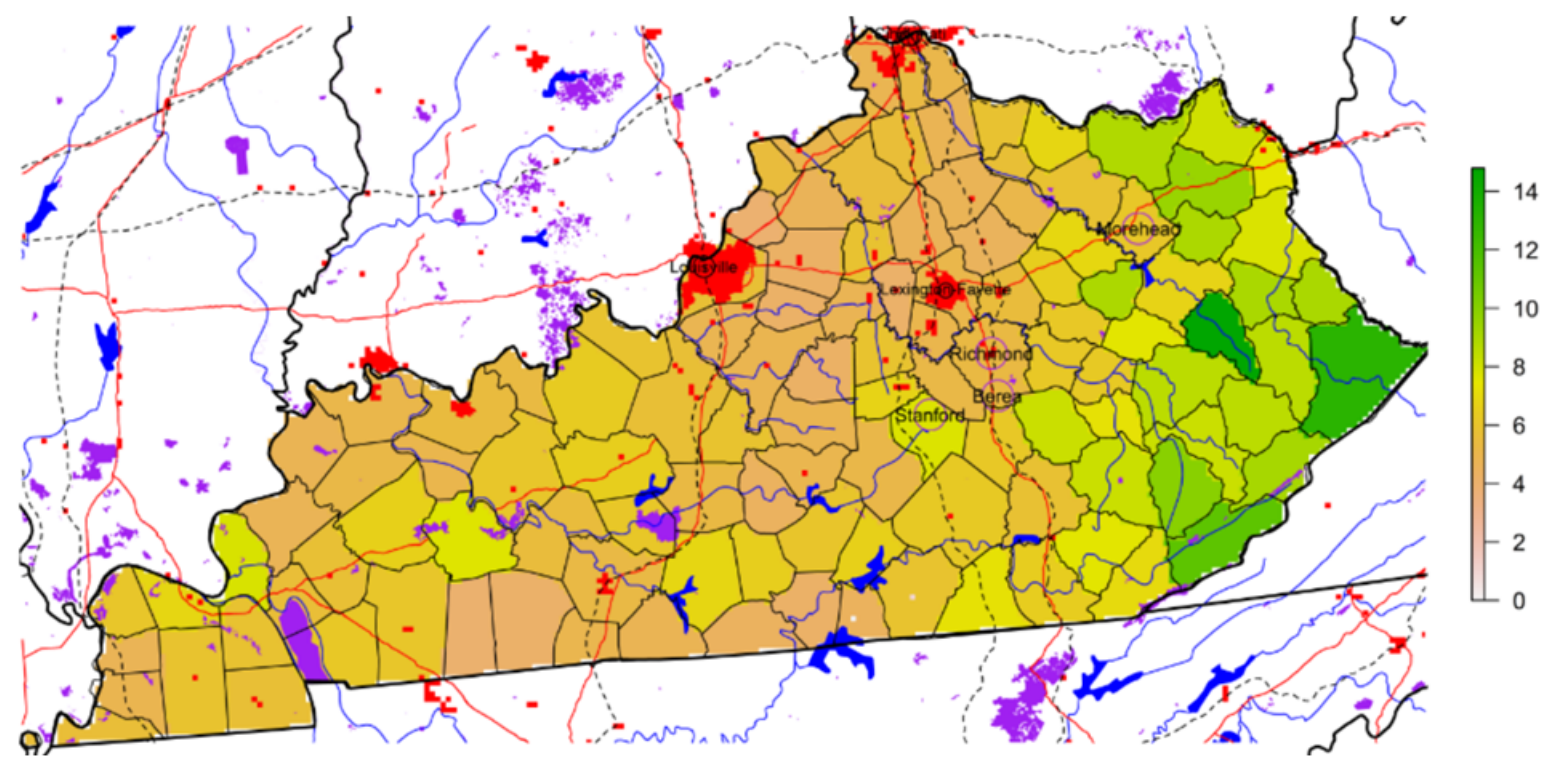




\section{Some remarks}

- Calculations for suitability are based on the limited set of selected indicators (public available worldwide data, added with data for energy production for Kentucky)

- Results should be used as a first step in the search for potential regions

- In a second step an interesting region should be investigated further with other detailed data and additional information (e.g. investment restrictions by local government). Such information is not present and not used in Global-Detector

More information

Wil.Hennen@wur.nl

0703358216

Peter.ravensbergen@wur.nl

0622461324

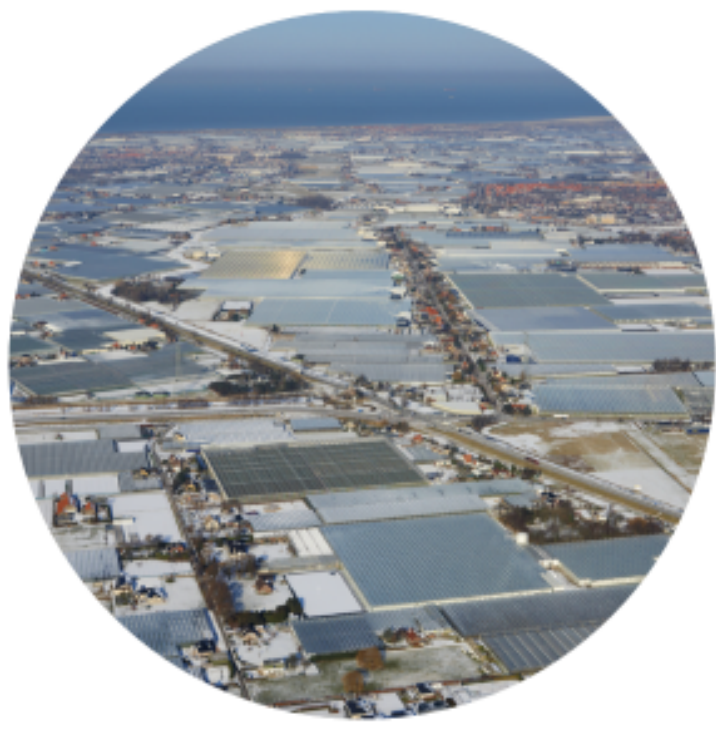


Wageningen Economic Research P.O. Box 29703

2502 LS The Hague

The Netherlands

$\mathrm{T}+31(0) 703358330$

E communications.ssg@wur.nl

www.wur.eu/economic-research

Wageningen Economic Research REPORT

2021-090
The mission of Wageningen University \& Research is 'To explore the potential of nature to improve the quality of life'. Under the banner Wageningen University \& Research, Wageningen University and the specialised research institutes of the Wageningen Research Foundation have joined forces in contributing to finding solutions to important questions in the domain of healthy food and living environment. With its roughly 30 branches, $6,800$ employees ( $6,000 \mathrm{fte})$ and 12,900 students, Wageningen University \& Research is one of the leading organisations in its domain. The unique Wageningen approach lies in its integrated approach to issues and the collaboration between different disciplines. 



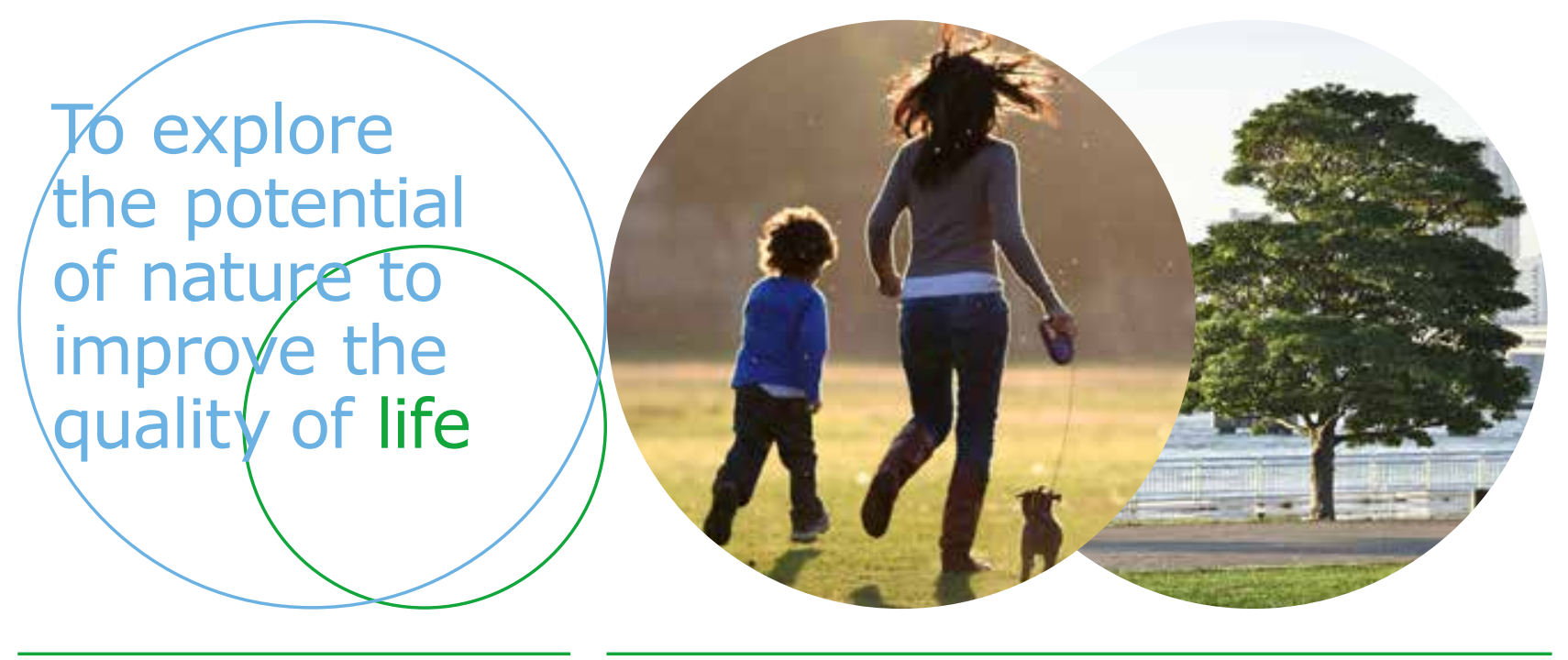

Wageningen Economic Research P.O. Box 29703

2502 LS Den Haag

The Netherlands

$\mathrm{T}+31(0) 703358330$

E communications.ssg@wur.nl

www.wur.eu/economic-research

Report 2021-090

ISBN 978-94-6395-881-3
The mission of Wageningen University \& Research is "To explore the potential of nature to improve the quality of life". Under the banner Wageningen University \& Research, Wageningen University and the specialised research institutes of the Wageningen Research Foundation have joined forces in contributing to finding solutions to important questions in the domain of healthy food and living environment. With its roughly 30 branches, 6,800 employees $(6,000 \mathrm{fte})$ and 12,900 students, Wageningen University \& Research is one of the leading organisations in its domain. The unique Wageningen approach lies in its integrated approach to issues and the collaboration between different disciplines. 